9

\title{
AS EXECUÇÕES FISCAIS E O PROTESTO \\ COMO ALTERNATIVA NA RECUPERAÇÃO DOS CRÉDITOS PÚBLICOS
}

Jéssica Lopes Pereira

\section{INTRODUÇÃO}

O Estado necessita, em sua atividade financeira, captar recursos financeiros para manter sua estrutura e prover as necessidades coletivas. Essa arrecadação é feita basicamente por tributos devidos pelo particular.

Esses tributos compõem a receita pública e também, conjuntamente com créditos não tributários, os créditos fazendários. $\mathrm{O}$ infortúnio da entrada desses créditos é a inadimplência que, infelizmente, não é situação rara.

Os créditos inadimplidos são cobrados pela via judicial esbarrando na morosidade do judiciário e consequentemente na demora na solução dos litígios ${ }^{1}$. A despeito das garantias do devido processo legal e da duração razoável do processo, o Poder Judiciário não vem correspondendo ao seu dever de prestar a adequada tutela jurisdicional.

Seja pela questão orçamentária, pela carência de pessoal (especialmente qualificado), ou pelo excessivo número de processos distribuídos diariamente, fato é que alternativas devem ser buscadas, visando alcançar um resultado que se preste a pacificar as relaçôes que são postas à sua análise de maneira eficiente, pois, ante a morosidade nem sempre é possível atingir a pretensão das partes ao ajuizar a

\footnotetext{
GONÇALVES, Marcelo Barbi. Execução fiscal: um retrato da inoperância, o (bom) exemplo português e as alternativas viáveis. Revista de Direito da Procuradoria Geral. Procuradoria Geral do Estado do Rio de Janeiro, jun. 2015, p. 206.
} 
-. Tributação, direitos fundamentais e desenvolvimento

demanda, muitas vezes tornando o processo inútil à finalidade a que lhe atribuiu quando da propositura da ação.

A crise da Justiça brasileira está instaurada, colocando em risco a segurança das relações jurídicas e a própria qualidade de vida dos cidadãos, ensejando a discussão acerca da reforma do atual sistema.

O congestionamento da Justiça conta com a contribuição das execuções fiscais, ao passo que nem sempre alcançam a satisfação do crédito. Assim, o procedimento convencional para cobrança dos créditos da Fazenda é alvo de severas críticas e ensejando a propositura de mudanças.

No presente trabalho, visamos à discussão acerca das execuções fiscais e o protesto das Certidões de Dívida Ativa como meio mais eficaz, podendo ser via alternativa ou mesmo aliado da cobrança judicial dos créditos públicos.

\section{CRÉDITOS PÚBLICOS E A INADIMPLÊNCIA}

\subsection{Créditos públicos}

Os créditos públicos são estudados dentro do campo do Direito Financeiro, disciplina que se tornou autônoma a partir da Constituição de $1946^{2}$. É o termo que os autores da disciplina costumeiramente usam como sinônimo de empréstimo público e dívida pública ou ainda para identificar situações envolvendo tanto as operações em que o Estado toma dinheiro como aquelas em que fornece pecúnia ${ }^{3}$.

O vocábulo, em regra, relaciona-se com a capacidade de o governo cumprir obrigaçôes financeiras, obter recursos da esfera privada nacional ou de organizações internacionais, por meio de empréstimos. O crédito público, quando materializado em empréstimos, dá origem à dívida pública ${ }^{4}$.

Entretanto, crédito público, no presente contexto, diz respeito aos créditos da Administração Pública em face de um contribuinte ou devedor, em virtude da

RIBEIRO, C. J. de Assis. O crédito público no Brasil: teoria e prática. Cadernos de Administração Pública. Fundação Getúlio Vargas. Rio de Janeiro, 1972, p. 2.

3 HARADA, Kiyoshi. Direito financeiro e tributário. 25. ed. rev., atual. e ampl. São Paulo: Atlas, 2016, p. 186.

4 Definição do termo no Glossário do Senado Federal. Disponível em: <https://www12.senado. leg.br/orcamento/glossario/credito-publico>. Acesso em: 23 jun. 2017. 
incidência de um tributo ou de uma multa administrativa aplicada ao particular, isto é, o crédito fiscal'5. É a receita destinada à manutenção da estrutura estatal, à cobertura de gastos governamentais com a prestação de serviços públicos e outras necessidades orçamentárias.

É fato que a devida aplicação dos recursos públicos, resguarda a estrutura econômica dos Estados de fatores como as pressões inflacionárias, a produção industrial ou agraria deficiente, a deficiência de transportes, meios de comunicação, fornecimento de energia, recursos humanos, desorganização do mercado, desequilíbrios regionais, ausência de adequada estrutura educacional, inclusive superior, e desequilíbrio orçamentário ${ }^{6}$.

Em via contrária, a má administração ou ainda a arrecadação deficitária de recursos fragiliza o Estado que encontrará dificuldade para o custeio de manutenção de sua estrutura, bem como para atender as necessidades da população.

\subsubsection{Crédito tributário}

Para manutenção da estrutura estatal faz-se necessário à busca de recursos financeiros. Assim, os tributos acompanham a história da humanidade de modo que desde as remotas formas de organização social já existiam alguma espécie de cobrança para os gastos coletivos, como os dízimos, cobrados no século XIII a.C. sobre frutos, carnes, óleo e mel, conforme lições de Luís Eduardo Shoueri.7

Ao longo da História, tributo significou desde pagamentos em dinheiro ou bens, exigidos pelos vencedores aos povos vencidos (espécie de indenização de guerra), ou ainda, a cobrança perante os próprios súditos decorrente da vontade do soberano, ora sob o disfarce de donativos, ora como um dever ou obrigação, até a atual definição, permeada pelos preceitos do Estado de Direito, de prestação exigida nos termos previamente definidos pela lei, através do qual os indivíduos contribuem para o custeio das despesas do Estado e das entidades de fins públicos em favor da coletividade.

\footnotetext{
PLAUSEN, Leandro; AVILA, René Bergmann; SLIWIKA, Indrid Schoroder. Direito processual tributário: processo administrativo fiscal e execução fiscal à luz da doutrina e da jurisprudência. 6. ed. Porto Alegre: Livraria do Advogado, 2010, p. 146.

6 RIBEIRO, C. J. de Assis. O crédito público no Brasil: teoria e prática. Cadernos de Administração Pública. Fundação Getúlio Vargas. Rio de Janeiro, 1972, p. 11-13.

7 SHOUERI, Luís Eduardo. Direito tributário. 2. ed. São Paulo: Saraiva, 2012, p. 19.
} 
•• Tributação, direitos fundamentais e desenvolvimento

Neste contexto, o Código Tributário Nacional define que:

Art. $3^{\circ}$ Tributo é toda prestação pecuniária compulsória, em moeda ou cujo valor nela se possa exprimir, que não constitua sanção de ato ilícito, instituída em lei e cobrada mediante atividade administrativa plenamente vinculada. (Grifo nosso).

Anteriormente a promulgação do CTN, a Lei n. 4.320/1964, relativa a normas gerais de Direito Financeiro e para elaboração e controle dos orçamentos e balanços dos entes federativos, estabelecia:

Art. 9o Tributo é a receita derivada instituída pelas entidades de direito público, compreendendo os impostos, as taxas e contribuições nos termos da constituição e das leis vigentes em matéria financeira, destinando-se o seu produto ao custeio de atividades gerais ou especificas exercidas por essas entidades. (Grifo nosso).

O tributo é receita derivada à medida que implica transferência ao Estado de riqueza gerada pelo particular, compondo a receita pública. Opóe-se a receita originária decorrente de uma atividade do Estado como agente econômico no mercado, gerando riquezas quer pela percepção de preços públicos, quer pela remuneração pelo emprego de patrimônio público (juros sobre empréstimos públicos, royalties pelo uso de bens públicos etc.).

Como principal fonte arrecadação de recursos financeiros aos cofres públicos, tornou-se protagonista de diversos estudos sobre sua influência na economia, bem como a busca de mecanismos que signifiquem maior eficiência na capitação desses tributos, assunto a ser discutido no decorrer do trabalho.

À luz do CTN (art. 4º), o fato gerador é o principal requisito para a existência e para a definição da natureza jurídica de um tributo. Entretanto, cabe esclarecer que a classificação de um tributo deve atender a critérios intrínseco (fato gerador, atividade vinculada ou não) e extrínseco (destinação do produto da arrecadação).

Assim, na tentativa de estabelecer as espécies tributárias, a doutrina subdividiu-se em teoria bipartite (ou dicotômica), tripartite (tricotômica) e quinquipartite (ou pentapartite).

A teoria bipartite diferencia os tributos em relação a uma vinculação ou não a uma atuação estatal, sendo eles taxas (vinculados) e impostos (não vinculados).

Segundo a teoria da divisão tripartite, adotada pelo CTN (art. 50), são espécies de tributos os impostos, as taxas e as contribuições de melhoria.

Após o advento da CRFB/88 que reconheceu cinco espécies tributárias, a teoria tripartite tornou-se insuficiente para a classificação dos tributos, já que não se 
presta à identificação das contribuições especiais e dos empréstimos compulsórios, identificados a partir de sua finalidade e previsão de restituição, respectivamente, dando origem a teoria quinquipartite.

Sob o espectro dessa teoria, com base na Carta Magna, são espécies tributárias os impostos (art. 145), taxas (art. 145), contribuições de melhoria (art. 145), empréstimos compulsórios (art. 148) e contribuições especiais (arts. 149 e 195).

Imposto é a espécie tributária cuja obrigação tem por fato gerador situação independentemente de qualquer atividade estatal específica, relativa à vida do contribuinte, à sua atividade ou a seu patrimônio (art. 16, CTN). Refere-se sempre a uma atividade do contribuinte capaz de revelar a sua capacidade contributiva, demonstração de riqueza.

As taxas (arts. 77 a 80 do CTN) ao contrário dos impostos, são vinculados a uma atuação estatal. A Constituição Federal expressa que as a União, os Estados, o Distrito Federal e os Municípios poderão instituir taxas "em razão do exercício do poder de polícia ou pela utilização, efetiva ou potencial, de serviços públicos específicos e divisíveis, prestados ao contribuinte ou postos a sua disposição" (art. 145 , II) e que terão base de cálculo própria de impostos (art. 145, $\$ 2$ o).

A contribuição de melhoria tem como fato gerador a valorização imobiliária ao contribuinte decorrente de obra pública. O valor do tributo não deve ser superior à valorização do imóvel, mesmo que a obra seja mais cara (limite individual), e não deve ser inferior ao custo da obra (limite global), de acordo com o art. 81, do CTN.

As contribuições especiais, prevista no art. 149 da Constituição Federal, são tributos arrecadados para serem gastos em finalidades específicas (seguridade social, atendimento de interesses de categorias profissionais, dentre outras), sendo, portanto, vinculados. Subdividem-se em: contribuições sociais, contribuições de intervenção no domínio econômico, as contribuições de interesse das categorias profissionais ou econômicas e as contribuições sobre a iluminação pública (149-A, CF).

O empréstimo compulsório é tributo de competência exclusiva da União, instituída por lei complementar, e de acordo com situações específicas dispostas no artigo 148, da Constituição Federal (guerra externa, calamidade pública etc.), ou seja, é tributo estritamente vinculado. Deve ser restituído ao contribuinte posteriormente. 
-. Tributação, direitos fundamentais e desenvolvimento

Os tributos, portanto, são prestações pecuniárias devidas ao ente federativo por um particular para compor a receita pública, constituindo junto respectivos adicionais e multas, o crédito fiscal de natureza tributária.

\subsubsection{Crédito não tributário}

Além dos tributos, são créditos da Administração Pública aqueles de natureza não tributária que se originam de exercício do poder de império, seja por atividade legalmente conferida à autoridade de direito público, seja do exercício do Poder de Polícia ${ }^{8}$, poder inerente ao Estado que limita o exercício dos direitos individuais em prol do interesse público.

José Carvalho Filho conceitua o poder de Polícia como "a prerrogativa de direito público que, calcada na lei, autoriza a Administração Pública a restringir o uso e o gozo da liberdade e da propriedade em favor do interesse da coletividade" 9

Encontramos no Código Tributário Nacional a definição de Poder de Polícia bem como condições para seu regular exercício ${ }^{10}$.

A atuação do Poder de Polícia se dá através de atos normativos (a lei), bem como de atos administrativos e operaçôes materiais que compreende medidas preventivas (fiscalização, vistoria, ordem, notificação, autorização, licença, por exemplo) e medidas repressivas (dissolução de reunião, interdição de atividade, apreensão de mercadorias deterioradas, por exemplo) ${ }^{11}$.

Decorre, ainda, do Poder de Polícia atos sancionatórios ante a prática de uma infração administrativa, preestabelecida em lei como tal, chamados de sanção de

GODOI, Marilei Fortuna et al. Execução fiscal aplicada. Analise pragmática do processo de execução fiscal. Salvador, 2015, p. 37.

9 CARVALHO FILHO, José dos Santos. Manual de direito administrativo. 27. ed. rev., ampl. e atual. até 31-12-2013. São Paulo: Atlas, 2014, p. 77.

10 CTN: Art. 78. Considera-se poder de polícia atividade da administração pública que, limitando ou disciplinando direito, interesse ou liberdade, regula a prática de ato ou abstenção de fato, em razão de interesse público concernente à segurança, à higiene, à ordem, aos costumes, à disciplina da produção e do mercado, ao exercício de atividades econômicas dependentes de concessão ou autorização do Poder Público, à tranquilidade pública ou ao respeito à propriedade e aos direitos individuais ou coletivos.

Parágrafo único. Considera-se regular o exercício do poder de polícia quando desempenhado pelo órgão competente nos limites da lei aplicável, com observância do processo legal e, tratando-se de atividade que a lei tenha como discricionária, sem abuso ou desvio de poder.

11 DI PIETRO, Maria Sylvia Zanella. Direito administrativo. 27. ed. São Paulo: Atlas, 2014, p. 126. 
polícia. As mais comuns são a multa, a inutilização de bens privados, a interdição de atividade, o embargo de obra, a cassação de patentes, a proibição de fabricar produtos etc.

Assim temos que as multas geram a obrigação de uma prestação pecuniária do particular para com o Poder Público, legalmente prevista como sanção pela prática de ato ilícito, por exemplo, uma infração a uma norma ambiental. Esse caráter sancionatório diferencia a multa do conceito de tributo, previsto no art. $3^{\circ}$ do $\mathrm{CTN}^{12}$.

Segundo Ricardo Lobo Torres, o tributo e a penalidade pecuniária são inconfundíveis, porque o tributo deriva da incidência do poder tributário sobre a propriedade privada, ao passo que a multa resulta do poder penal do Estado e tem por objetivo resguardar a validade da ordem jurídica ${ }^{13}$.

O crédito não tributário, conforme se extrai do art. 39, $\$ 2^{\circ}$, da Lei n. 4.320/64, são os créditos da Fazenda Pública provenientes de empréstimos compulsórios, contribuições estabelecidas em lei, multa de qualquer origem ou natureza, exceto as tributárias, foros, laudêmios, alugueis ou taxas de ocupação, custas processuais, preços de serviços prestados por estabelecimentos públicos, indenizações, reposições, restituições, alcances dos responsáveis definitivamente julgados, bem assim os créditos decorrentes de obrigações em moeda estrangeira, de sub-rogação de hipoteca, fiança, aval ou outra garantia, de contratos em geral ou de outras obrigações legais etc.

Entretanto, o crédito não tributário que se permite inscrever em dívida ativa e, consequentemente objeto de uma futura Execução Fiscal, são aqueles créditos originários de atividade típica de direito público própria da credora fazendária, baseada na lei, no exercício do poder de império ou contrato ${ }^{14}$.

Tantos créditos tributários quanto os não tributários, passíveis de inscrição em dívida ativa, têm como credora a Administração Pública e, em caso do não pagamento voluntário do devedor, exigem um procedimento próprio para sua cobrança.

12 IANCZKOVSKI, Elvis. O tributo e a multa: alguns pontos de convergência e divergência. Conteúdo Juridico, Brasilia-DF: 11 jun. 2012. Disponível em: <http://www.conteudojuridico. com.br/artigo,o-tributo-e-a-multa-alguns-pontos-de-convergencia-e-divergencia, 37477. html\#_edn3>. Acesso em: 20 jun. 2017.

13 TORRES, Ricardo Lobo. Curso de direito financeiro e tributário. 17. ed. Rio de Janeiro: Renovar, 2010, p. 238.

14 GODOI, Marilei Fortuna et al. Execução fiscal aplicada. Analise pragmática do processo de execução fiscal. Salvador, 2015, p. 38. 
•• Tributação, direitos fundamentais e desenvolvimento

\subsection{Inadimplência, inscrição em dívida ativa e execução fiscal}

$\mathrm{Na}$ falta de cumprimento voluntário de uma obrigação pecuniária, tributária ou não tributária, após esgotado o prazo para pagamento assinado ao sujeito passivo, os débitos serão inscritos em Dívida Ativa, em registro próprio ${ }^{15}$, após apurada a sua liquidez e certeza, e a respectiva receita será escriturada a esse título ${ }^{16}$.

A dívida ativa ${ }^{17}$ é crédito do Estado a ser cobrado executivamente e contrapõe-se a dívida pública que é o débito do poder público para com terceiros ${ }^{18}$.

Os créditos da Fazenda Pública serão incluídos no cadastro da dívida ativa através do Termo de Inscrição em Dívida Ativa, documento público extremamente formal que deve conter os requisitos obrigatórios do art. $2^{\circ}, \$ 5^{\circ}$ da Lei de Execuções Fiscais (Lei n. 6.830/80) e art. 202, parágrafo único do CTN, relativos à identificação do devedor e corresponsáveis, valor devido, fundamento legal, data de inscrição, identificação do processo administrativo que houver, mais a indicação do livro e folha da inscrição. Tal documento serve de base à Certidão de Dívida Ativa (CDA) que deve conter os mesmos requisitos formais exigidos do termo de inscrição.

A Certidão de Dívida Ativa constitui título executivo extrajudicial, conforme dispõe o art. 784, IX, do Código de Processo Civil, dotado de certeza, liquidez e exigibilidade, tornando idônea a ser cobrada por ação de execução ${ }^{19}$, cabendo o ônus probatório ao sujeito passivo que pretenda desconstituí-la, exigindo-se para tal prova inequívoca (art. 204 do CTN e art. $3^{\circ}$ da Lei n. 6.830/80).

A CDA é o título que embasa a execução fiscal, que se inicia por uma petição inicial indicando o juiz a quem é dirigida, o pedido e o requerimento para a citação do executado, nos termos do art. $6^{\circ}$ da Lei de Execuções Fiscais, ou seja, mais simplificada quando comparada a norma do art. 319, do CPC.

A inscrição do crédito tributário em dívida ativa não suspende ou interrompe a prescrição, diferentemente do crédito não tributário em que haverá suspensão do

AMARO, Luciano. Direito tributário brasileiro. 20. ed. São Paulo: Saraiva, 2014, p. 345.

Art. 39, $\$ 1^{\circ}$, da Lei n. 4.320, de 17 de Março de 1964.

Art. $2^{\circ}$ Constitui Dívida Ativa da Fazenda Pública aquela definida como tributária ou não tributária na Lei n. 4.320, de 17 de março de 1964, com as alteraçôes posteriores, que estatui normas gerais de direito financeiro para elaboração e controle dos orçamentos e balanços da União, dos Estados, dos Municípios e do Distrito Federal (Lei n. 6.830/80).

18 HARADA, Kiyoshi. Direito financeiro e tributário. 25. ed. rev., atual. e ampl. São Paulo: Atlas, 2016, p. 186.

19 AMARO, Luciano. Direito tributário brasileiro. 20. ed. São Paulo: Saraiva, 2014, p. 346. 
prazo prescricional pelo prazo de 180 dias ou até a distribuição da execução fiscal, se ocorrer antes do término do referido prazo (art. $2^{\circ}, \$ 3^{\circ}$, da Lei n. 6.830/80 $)^{20}$.

Em que pese à importância dos créditos públicos, inclusive atribuindo-lhes garantias e privilégios peculiares, existem limitações que vinculam o Poder Público, de modo que a arrecadação e até mesmo a adoção de meios mais eficientes, não podem ser feitas a qualquer custo.

\subsection{Princípios}

$\mathrm{O}$ poder de tributar advém da soberania do Estado, entretanto um conjunto de normas e princípios limitam a atuação do Estado quanto ao modo, a forma e a intensidade, que englobam regras de competência tributária, princípios constitucionais tributários e as imunidades ${ }^{21}$.

Em outras palavras, o Poder Público, ao exercer a tributação está cercado por demarcações que determinam seu exercício, seja pelas normas constitucionais, seja pelas normas infraconstitucionais, que estabelecem critérios materiais, quantitativos e formais, prestando-se a amparar os direitos fundamentais dos cidadãos e dos contribuintes.

A Constituição da República Federativa do Brasil aduz limitações constitucionais ao poder de tributar, como por exemplo: Legalidade Tributária (art. 150, I); Anterioridade Tributária (art. 150, III, $b$ e c); Isonomia Tributária (art. 150, II); Irretroatividade Tributária (art. 150, III, a); Vedação ao Confisco (art. 150, IV); Não limitação ao Tráfego de Pessoas e Bens e a Ressalva do Pedágio (art. 150, V); Uniformidade Geográfica (art. 151, I); Proibição da tributação federal diferenciada da renda da dívida pública e da remuneração dos agentes, em âmbito não federal (art. 151, II); Proibição das Isenções Heterônomas (art. 151, III) ${ }^{22}$.

Além as regras específicas à tributação, deve-se atentar que as diretrizes constitucionais que devem pautar toda e qualquer atuação da Administração Pública Direta ou Indireta, elencados no art. 37, caput, do Texto Constitucional ${ }^{23}$.

20 GODOI, Marilei Fortuna et al. Execução fiscal aplicada. Analise pragmática do processo de execução fiscal. Salvador, 2015, p. 61.

21 AMARO, Luciano. Direito tributário brasileiro. 20. ed. São Paulo: Saraiva, 2014, p. 90.

22 SABBAG, Eduardo. Manual de direito tributário. 8. ed. São Paulo: Saraiva, 2016, p. 59.

23 Art. 37. A administração pública direta e indireta de qualquer dos Poderes da União, dos Estados, do Distrito Federal e dos Municípios obedecerá aos princípios de legalidade, impessoalidade, moralidade, publicidade e eficiência. 
-. Tributação, direitos fundamentais e desenvolvimento

Da mesma forma, a Constituição prevê os princípios processuais (do devido processo legal de da razoável duração do processo) que devem ser observados no processo executivo promovido pela Fazenda Pública na cobrança de seus créditos.

Dentre tais princípios destacaremos alguns mais pertinentes ao presente estudo, sem a pretensão de esgotá-los.

\subsubsection{Princípio da legalidade}

O Estado de Direito é indissociável da concepção de legalidade, sendo tal princípio informado pela ideia de justiça e segurança jurídica.

Enquanto o Poder Público está ligado ao princípio da legalidade strito senso, isto é, os entes públicos estão vinculados à lei, agindo dentro dos ditames legais na forma do art. 37, caput, da Constituição da República Federativa do Brasil, a legalidade associada ao particular relaciona-se com a autonomia da vontade disposta no art. 5º, inciso II, da Carta Magna, de modo que "ninguém será obrigado a fazer ou deixar de fazer alguma coisa senão em virtude de lei”.

Assim, conforme o princípio da legalidade ou da tipicidade tributária, não é possível a nenhum dos entes políticos criar ou majorar tributos sem lei prévia que o estabeleça, na forma do artigo 150, I da Constituição da República Federativa do Brasil de $1988^{24}$.

Como consequência desse princípio, a lei deve determinar a situação necessária e suficiente à ocorrência da obrigação principal e a quantificação do tributo, não bastando à mera autorização legislativa para a cobrança do tributo ${ }^{25}$. Em outras palavras, cabe à lei determinar todos os dados necessários à cobrança de determinado tributo ou ainda situação de eventual isenção, anistia ou remissão, sem que haja espaço para a atuação discricionária da autoridade.

Tal princípio também está previsto no art. 97, do Código Tributário Nacional.

Art. 97. Somente a lei pode estabelecer:

I - a instituição de tributos, ou a sua extinção;

II - a majoração de tributos, ou sua redução, ressalvado o disposto nos artigos 21, 26, 39,57 e 65 ;

24 CF: Art. 150. Sem prejuízo de outras garantias asseguradas ao contribuinte, é vedado à União, aos Estados, ao Distrito Federal e aos Municípios: I - exigir ou aumentar tributo sem lei que o estabeleça;

25 AMARO, Luciano. Direito tributário brasileiro. 20. ed. São Paulo: Saraiva, 2014, p. 94. 
III - a definição do fato gerador da obrigação tributária principal, ressalvado o disposto no inciso I do $\$ 3^{\circ}$ do artigo 52 , e do seu sujeito passivo;

IV - a fixação de alíquota do tributo e da sua base de cálculo, ressalvado o disposto nos artigos 21, 26, 39, 57 e 65;

$\mathrm{V}$ - a cominação de penalidades para as ações ou omissôes contrárias a seus dispositivos, ou para outras infraçôes nela definidas;

VI - as hipóteses de exclusão, suspensão e extinção de créditos tributários, ou de dispensa ou redução de penalidades.

Em regra, exige-se lei em sentido formal, isto é, formulada por órgão titular de função legislativa, mas admite exceção constitucional de que por ato do Poder Executivo se opere a redução da alíquota de alguns impostos e contribuição de intervenção no domínio econômico e, uma vez reduzida, pode restabelecê-la. Porém, deve ser observado o estrito cumprimento das condições especificadas em lei.

Outro ponto a ser destacado é que, em regra, a lei responsável pela criação do tributo é a lei de natureza ordinária, entretanto, a própria Constituição Federal prevê que determinados tributos devem ser criados por lei complementar (arts. 148 , 153, VII, e 154, I) e se não observada tal exigência, a criação do tributo afrontaria diretamente a $\mathrm{CRFB} / 88$, ensejando a declaração de inconstitucionalidade formal da norma.

\subsubsection{Princípio da eficiência na Administração Pública}

A Emenda Constitucional 18/1998, às aspirações da Reforma Administrativa, promoveu profundas alterações na Constituição, inserindo entre os princípios constitucionais da Administração Pública, previstos no art. 37, caput, o princípio da eficiência ${ }^{26}$.

A respeito do referido princípio, Maria Sylvia Zanella Di Pietro leciona:

O princípio da eficiência apresenta, na realidade, dois aspectos: pode ser considerado em relação ao modo de atuação do agente público, do qual se espera o melhor desempenho possível de suas atribuições, para lograr os melhores resultados; e em relação ao modo de organizar, estruturar, disciplinar a Administração Pública, também com o mesmo objetivo de alcançar os melhores resultados na prestação do serviço público ${ }^{27}$.

26 COELHO, Bernardo Bichara Faria. Breves considerações acerca da arbitragem e os princípios da Administração Pública. Revista de Direito da Procuradoria Geral, Procuradoria Geral do Estado do Rio de Janeiro. Junho 2014, p. 54.

27 DI PIETRO, Maria Sylvia Zanella. Direito administrativo. 27. ed. São Paulo: Atlas, 2014, p. 84. 
-. Tributação, direitos fundamentais e desenvolvimento

O princípio da eficiência, chamado por Celso Bandeira de Mello de princípio da boa administração ${ }^{28}$, consiste na busca pela Administração Pública do melhor emprego de seus recursos humanos, materiais e institucionais, para melhor satisfazer as necessidades coletivas ${ }^{29}$, visando maior qualidade na atividade pública, na prestação de serviços públicos bem como na gestão orçamentária, devendo ser observado também atuação da Fazenda Pública na recuperação dos créditos públicos.

\subsubsection{Princípios do devido processo legal e da duração razoável do processo}

Persistindo em aberto o débito perante a Fazenda Pública, faz-se necessário o manejo de um processo executivo contra o devedor a fim de liquidar a dívida, a Execução Fiscal. O processo executivo deve ocorrer sem arbitrariedades, seguindo preceitos processuais constitucionais como o devido processo legal e a duração razoável do processo.

O devido processo legal é direito fundamental, esculpido na Constituição Federal, em seu art. 5, LIV: "ninguém será privado da liberdade ou de seus bens sem o devido processo legal". Significa dizer que a todos é garantido processo justo e equitativo.

A garantia ao processo legal, não se limita ao âmbito dos processos judiciais, mas alcança a esfera legislativa e administrativa, assegurando o combate ao abuso de poder em qualquer ramo ${ }^{30}$.

O devido processo legal pressupõe a observância de garantias mínimas nas causas em juízo como: juiz natural e competente (CF, art. 5º inc. XXXVII e LIII), a garantia de acesso à Justiça (CF, art. 5\%, inc. XXXV), ampla defesa e contraditório $(\mathrm{CF}$, art. 50, inc. LV) e fundamentação de todas as decisões judiciais (art. 93, inc. IX) $)^{31}$.

28 MELLO, Celso Antonio Bandeira de. Curso de direito administrativo. 26. ed. São Paulo: Malheiros, 2008, p. 122.

29 SILVA, José Afonso da. Comentário contextual a Constituição. 8. ed. São Paulo: Malheiros, 2010, p. 342.

30 DIDIER JR., Fredie. Curso de direito processual civil: introdução ao direito processual civil, parte geral e processo de conhecimento. 17. ed. Salvador: JusPodivm, 2015, p. 63.

31 THEODORO JUNIOR, Humberto. Curso de direito processual civil. Rio de Janeiro: Forense, 2014, v. I: Teoria geral do direito processual civil e processo de conhecimento, p. 182. 
As execuções fiscais e o protesto como alternativa na recuperação dos créditos públicos

Essa determinação Constitucional transcende a mera submissão de formas e procedimentos prescritos em lei, devendo dirigir-se a um processo justo, isto é, realizar o melhor resultado no concreto ${ }^{32}$.

Não obstante, o princípio da duração razoável do processo está inserido no texto constitucional entre os direitos fundamentais (art. 50, inc. LXXVIII): " a todos, no âmbito judicial e administrativo, são assegurados a razoável duração do processo e os meios que garantam a celeridade de sua tramitação".

O princípio é ratificado pelo CPC no art. 40, que ressalta sua aplicação à fase executiva, e no inciso II, do art. 139, incumbindo ao magistrado velar pela duração razoável do processo ao conduzir o processo.

Assim temos que o processo, seja ele de conhecimento ou executivo, deve realizar-se sem arbitrariedades buscando o melhor resultado no caso concreto, em tempo necessário e adequado à solução do caso, conferindo efetividade a prestação jurisdicional.

THEODORO JÚNIOR leciona que para se pensar em um processo justo é necessário efetividade e acrescenta:

(...) não sendo rápida a resposta do juízo para a pacificação do litígio a tutela não se revela efetiva. Ainda que afinal se reconheça e proteja o direito violado, o longo tempo em que o titular, no aguardo do provimento judicial, permaneceu privado de seu bem jurídico, sem razão plausível, somente pode ser visto como uma grande injustiça. Daí por que, sem necessidade de maiores explicaçôes, se compreende que o Estado não pode deixar de combater a morosidade judicial e que, realmente, é um dever primário e fundamental assegurar a todos quantos dependam da tutela da Justiça uma duração razoável para o processo e um empenho efetivo para garantir a celeridade da respectiva tramitação $0^{33}$.

Dessa forma, o processo executivo fiscal deve se realizar sob o espectro do devido processo legal e da duração razoável do processo, proporcionando uma solução efetiva à pretensão fazendária na recuperação de seus créditos.

\section{A COBRANÇA DOS CRÉDITOS FISCAIS}

Como já dissemos, o crédito da Fazenda Pública não adimplido em prazo oportuno, é inscrito em dívida ativa, formalizando o título executivo, chamado de Certidão de Dívida Ativa, que embasará a ação executiva.

32 Op. cit., p. 182.

33 THEODORO JUNIOR, Humberto. Curso de direito processual civil. Rio de Janeiro: Forense, 2014, v. I: Teoria geral do direito processual civil e processo de conhecimento, p. 227-228. 
-. Tributação, direitos fundamentais e desenvolvimento

O Código de Processo Civil trata do procedimento de execução fundada em títulos extrajudiciais a partir do art. 771. Todavia, os procedimentos de execução fundados em Certidões de Dívida Ativa, denominados de execuções fiscais, seguem procedimento especial previsto na Lei n. 6.830/80, aplicando- se subsidiariamente o Código de Processo Civil, diferenciando-a da execução dos demais títulos executivos, regulada pelo CPC.

\subsection{Lei $n .6 .830 / 80$}

Um sistema legislativo específico de cobrança dos créditos da Fazenda Pública foi instituído pelo Decreto-Lei n. 960 de 17 de dezembro de 1938, que unificou o executivo fiscal para todos os entes públicos e disciplinou os créditos passíveis de serem por eles cobrados ${ }^{34}$.

O diploma perdurou, com algumas modificações até o advento do Código de Processo Civil em 1973, passando a execução fiscal a ser regida pelas mesmas normas gerais que disciplinavam a execução de créditos entre particulares.

Posteriormente, a Lei n. 6.830/80 retirou o executivo fiscal do âmbito do Código de Processo Civil, conferindo-lhe regime especial, aplicando o Código de Processo Civil apenas em caráter subsidiário.

Desse modo, a execução fiscal no Brasil é regida pela Lei n. 6.830, de 22 de setembro de 1980, que estabeleceu nova disciplina de cobrança da dívida ativa (tributária e não tributária) da Fazenda Pública da União, Estados e Municípios, e respectivas autarquias.

A cobrança do crédito fiscal através de um procedimento próprio intentou acelerar a satisfação coativa, em prol do interesse público que se reveste tais créditos ${ }^{35}$.

$\mathrm{O}$ procedimento executivo fiscal inaugura-se através de uma petição da $\mathrm{Fa}$ zenda Pública competente, que é o exequente, sendo seu objeto o recebimento de um crédito público, de natureza tributária ou não tributária, consubstanciado em uma Certidão de Dívida Ativa (CDA), cujos requisitos estão previstos no $\$ 5^{\circ}$, do artigo $2^{\circ}$, da Lei de Execução Fiscal. São eles: o nome do devedor e dos correspon-

VARGA, Caio Amuri. Desjudicialização das execuções fiscais tributárias como medida de auxílio ao descongestionamento do Poder Judiciário. 2015. Dissertação (Mestrado em Direito) - Universidade Presbiteriana Mackenzie, São Paulo, p. 37.

35 GODOI, Marilei Fortuna et al. Execução fiscal aplicada. Analise pragmática do processo de execução fiscal. Salvador, 2015, p. 31. 
sáveis e, sempre que conhecido, o domicílio ou residência de um e de outros; o valor originário da dívida, bem como o termo inicial e a forma de calcular os juros de mora e demais encargos previstos na lei de regência do débito executado; a origem, a natureza e o fundamento legal ou contratual da dívida; a indicação, se for o caso, de estar a dívida sujeita à atualização monetária, bem como seu respectivo fundamento legal e o termo inicial para seu cálculo; a data e o número da inscrição em dívida ativa, e, por fim, o número do processo administrativo ou do auto de infração, se neles estiver apurado o valor da dívida.

A ação poderá ser movida contra o devedor, o fiador, o espólio, a massa falida, o responsável, nos termos da lei, por dívidas, tributárias ou não, de pessoas físicas ou pessoas jurídicas de direito privado, e ainda, os sucessores a qualquer título.

Uma vez distribuído o processo de execução, o juiz que ordenará além da citação, providências no sentido de se garantir a dívida caso, no prazo de cinco dias o executado não pagar, não efetuar o depósito, não oferecer fiança bancária, nem nomear bens próprios ou de terceiros à penhora.

Se ultrapassado os cinco dias sem qualquer providência por parte do mesmo caberá a Fazenda Pública indicar bens passíveis de penhora (art. 18), porém se garantido o juízo o devedor poderá oferecer embargos à execução (art. 16) no prazo de 30 dias contados do depósito, juntada da prova da fiança bancária ou do seguro garantia ou da intimação da penhora. Isto é, a defesa do executado poderá ser feita através de um novo processo em curso perante o Poder Judiciário.

A penhora ou arresto dos bens deve seguir a ordem do art. 11, da Lei: dinheiro, título da dívida pública, bem como título de crédito, que tenham cotação em bolsa, pedras e metais preciosos, imóveis, navios e aeronaves, veículos, móveis ou semoventes e direitos e ações. Excepcionalmente, a penhora poderá recair, ainda, sobre estabelecimento comercial, industrial ou agrícola, bem como em plantações ou edifícios em construção na forma do $\mathbb{S} 1^{\circ}$, do mencionado artigo.

Malgrado a instituição do atual modelo de cobrança dos créditos públicos visasse a efetividade da cobrança não tem sido o que ocorre na prática, como se discorrerá a seguir.

\subsection{Aspectos negativos do atual modelo da Lei $\mathbf{n}$. 6.830/80}

O Conselho Nacional de Justiça (CNJ), anualmente divulga relatórios acerca da realidade dos tribunais brasileiros e trata a questão do congestionamento do Poder Judiciário, sob o enfoque da redução numérica dos processos em trâmite. 
-. Tributação, direitos fundamentais e desenvolvimento

Segundo o CNJ, no relatório Justiça em Números 2016 (ano-base 2015), verifica-se que a cada publicação do Relatório Justiça em Números destaca-se o impacto negativo gerado pela fase de execução nos dados de litigiosidade do Poder Judiciário brasileiro, aumentando o volume de processos e a já alta taxa de congestionamento.

Especificamente em relação às execuções fiscais (tributárias e não tributárias), a situação é ainda mais alarmante, pois representam, aproximadamente, 39\% de casos pendentes e 75\% das execuções pendentes no Poder Judiciário.

Apesar do elevado número de execuções fiscais que ingressam no sistema do Poder Judiciário, é o setor em que há a menor baixa de processos, provocando uma taxa de congestionamento no patamar de $91,9 \%$ e correspondem a um acréscimo de nove pontos percentuais a taxa de congestionamento do Poder Judiciário no ano de $2015^{36}$.

O processo executivo fiscal impacta todo o funcionamento da máquina judiciária, considerando o grande volume das ações distribuídas e significativo número dos processos pendentes.

As execuções fiscais perseguem crédito público que devia retornar ao erário, entretanto, na prática nem sempre alcançam seu propósito, seja pela inexistência de bens executáveis pelo devedor, pela não localização do mesmo, ou ainda, pela ocorrência de decadência ou prescrição da dívida.

Em estudo realizado pelo Instituto de Pesquisa Econômica Aplicada (IPEA) ${ }^{37}$ no ano de 2011, em cooperação com o CNJ, relativamente às execuçôes fiscais em trâmite perante a Justiça Federal, denominado Custo unitário do processo de execução fiscal da União, verificou-se que o tempo médio total de tramitação do processo executivo fiscal no âmbito federal é de oito anos, dois meses e nove dias e seu custo médio total provável é de $\mathrm{R} \$ 4.685,39$ (quatro mil, seiscentos e oitenta e cinco mil e trinta e nove centavos), muitas vezes, maior que o proveito econômico obtido.

Entretanto, cabe estabelecer que o referido período corresponde ao tempo entre a distribuição e a baixa que pode ocorrer por diversos motivos e não só pela

36 CONSELHO NACIONAL DE JUSTIÇA. Justiça em números. Brasília, 2016. Disponível em: <http://www.cnj.jus.br/programas-e-acoes/pj-justica-em-numeros/relatorios>. Acesso em: 2 jan. 2017, p. 61.

37 INSTITUTO DE PESQUISA ECONÔMICA APLICADA (Ipea). Custo Unitário do Processo de Execução Fiscal na Justiça Federal. Brasília, DF: Ipea, 2011. Disponível em: <http:// repositorio.ipea.gov.br/bitstream/11058/887/1/livro_custounitario.pdf>. Acesso em: 5 mar. 2017. 
As execuções fiscais e o protesto como alternativa na recuperação dos créditos públicos

liquidação da dívida, ou seja, não se que dizer que após oito anos, dois meses e nove dias, o crédito público terá ingressado nos cofres públicos sendo o problema muito mais complexo.

Ainda segundo dados do IPEA ${ }^{38}$, as execuções fiscais no âmbito federal enfrentam problemas já na integralização da relação processual, de modo que em $56,8 \%$ dos processos ocorre pelo menos uma tentativa frustrada de citação, e em $36,3 \%$ dos casos não há qualquer citação válida. Em 46,2\% dos executivos fiscais o devedor não é encontrado pelo sistema de Justiça.

Um dos motivos dessa dificuldade inicial pode se dar em razão de os cadastros dos devedores nas Fazendas Públicas são desatualizados e muitas vezes insuficientes, o que atrasa ainda mais o curso da execução e localização do executado.

Em relação à penhora, apenas em 15,7\% dos casos há penhora de bens, na grande maioria decorrente de expropriação e não da apresentação voluntária de bens pelo devedor. Entretanto, só 2,8\% das ações de execução fiscal, na Justiça Federal, resultam em algum leilão judicial (com ou sem êxito) e somente $0,3 \%$ dos casos o bem leiloado gera recursos suficientes para satisfazer a integralmente do débito, enquanto a adjudicação dos bens do executado extingue a dívida em $0,4 \%$ dos casos

Não bastassem todos os apontamentos acerca da ineficiência da execução fiscal em satisfazer o credito público, a inutilidade de todo gasto para manter as execuçôes em curso fica mais evidente quando se observa que 36,8\% dos casos são baixados desinente a prescrição ou decadência, 18,8\% pelo cancelamento da inscrição do débito, 13\% pela remissão e o pagamento representa apenas $25 \%$.

O nível de ineficácia é tal que, em 2013, a dívida ativa da União chegou a $R \$$ 1,273 trilhão, enquanto $\mathrm{R}$ \$ 23,4 bilhões foi recuperado pelo Executivo ${ }^{39}$.

Não obstante os dados serem baseados em estudo realizado na Justiça Federal, não é exclusividade dessa Justiça, sendo a inefetividade das execuções fiscais uma realidade qualquer que seja a Justiça ou o ente político exequente.

38 INSTITUTO DE PESQUISA ECONÔMICA APLICADA (Ipea). Custo Unitário do Processo de Execução Fiscal na Justiça Federal. Brasília, DF: Ipea, 2011. Disponível em: <http://www. ipea.gov.br/agencia/images/stories/PDFs/nota_tecnica/111230_notatecnicadiest1.pdf >. Acesso em: 5 jun. 2017.

39 CÂMARA DOS DEPUTADOS. Divida ativa supera arrecadação; propostas para agilizar cobrança não andam. Disponível em: <http:/www2.camara.leg.br/camaranoticias/noticias/ ECONOMIA/480908-DIVIDA-ATIVASUPERA-ARRECADACAO;-PROPOSTAS-PARA-AGILIZAR-COBRANCA-NAO-ANDAM.html>. Acesso em: 15 fev. 2017. 
-. Tributação, direitos fundamentais e desenvolvimento

Recentemente o Tribunal de Justiça de Minas Gerais apurou que o tempo médio de tramitação de uma execução fiscal municipal é de 4,4 anos, enquanto uma execução estadual dura em torno de 10,8 anos e uma execução Federal, 8,4 anos e que cada execução custa $\mathrm{R} \$ 4.000,00$, em média, aos cofres públicos ${ }^{40}$.

As execuçôes fiscais representam parte significativa dos processos ajuizados e possui altíssima taxa de congestionamento, contribuindo para o agravamento da crise do Judiciário e, como uma via de mão dupla, o agravamento da situação da morosidade do Poder Judiciário, prejudica a devida prestação jurisdicional, especialmente, no âmbito das ações de execução fiscal.

Outro relevante objeto das críticas ao procedimento executivo fiscal diz respeito ao valor executado, que não raras vezes são muito inferiores ao próprio custo do processo e que servem apenas para banalizar ainda mais esta classe de açóes, abarrotar o Poder Judiciário e acarretar mais trabalho às Procuradorias ${ }^{41}$.

A recuperação dos créditos públicos vem sendo um desafio a Administração Pública, com clara afronta ao Princípio da Eficiência dirigido ao Poder Público, disposto no art. 37, da Constituição Federal. Além de nem sempre resultarem em ingresso de receita ao erário ainda geram gastos ao exequente para mantê-la em curso.

Notadamente, a ineficiência do meio de cobrança das dívidas junto ao Poder Público representa, especialmente em relação aos tributos, menos dinheiro para prestação de serviços públicos à população, mas não só. Também são incentivo ao não pagamento das dívidas públicas e retroalimentam a crise do Judiciário.

\subsection{Repercussão social da inadimplência dos créditos públicos}

A ineficiência do atual modelo processual da execução fiscal se presta a atulhar o Poder Judiciário de processos que, em sua grande maioria, serão extintos sem a recuperação de ativos.

40 TRIBUNAL DE JUSTIÇA DE MINAS GERAIS. Cartilha execução fiscal eficiente. Disponível em: <http:/www.tjmg.jus.br/data/files/E3/A3/F4/96/18F6E4105A4805E40D4E08A8/ Cartilha_WEB.pdf>. Acesso em: $21 \mathrm{dez} .2016$.

41 ROCHA, Dartanhan Vercingetórix de Araújo e. Análise econômica das execuçôes fiscais de reduzido valor e os efeitos da Lei n. 12.514/11. Revista CEJ, Brasília, ano XVI, n. 56, p. $102-$ 110, jan./abr. 2012. Disponível em: <http://www.cjf.jus.br/ojs2/index.php/revcej/article/ view/1542/1550>. Acesso em: 3 jan. 2017. 
As execuções fiscais e o protesto como alternativa na recuperação dos créditos públicos

Assim, recursos que deveriam integrar as receitas públicas estão nas mãos de maus pagadores e a prestação de serviços públicos e a própria atuação da Administração Pública se vêm comprometidos.

Também, na medida em que o não pagamento tempestivo de tributos não é seguido de açôes efetivas por parte do credor para receber aquilo que lhe cabe, há um incentivo a uma cultura de protelamento e não pagamento de tributos e dívidas junto ao Poder Público.

Ante a massa de inadimplência contumaz, os Governos se vêm obrigados a aprovar periodicamente programas especiais de parcelamento que prestigiam os maus pagadores, oferecendo-lhes incentivos (descontos em multas e juros) para regularização de suas pendências tributárias. Entretanto, ainda assim não se recupera o devido, já que, não raras vezes, ocorre interrupção do pagamento e posteriormente novo parcelamento que podem incluir os débitos decorrentes de acordos anteriormente não cumpridos.

Ademais, à inadimplência contumaz são potencialmente causadoras de danos à livre concorrência, influenciando negativamente no equilíbrio competitivo do mercado.

Luciano de Souza Godoy e Juliana Penha Basso ${ }^{42}$ ponderam que, no Brasil, a partir da década de 90, a sonegação começou a ser trabalhada não só sob a ótica de um problema afeto aos entes públicos, mas como uma questão que atinge a própria sociedade. Consideram ainda que:

Os prejuízos concorrenciais decorrentes da sonegação fiscal são gerados pela quebra da igualdade nas condiçôes de competir. O empresário que pratica a sonegação fiscal pode se utilizar da "poupança" propiciada pelo não pagamento dos tributos, a fim de colocar em seus produtos preços inferiores aos dos seus concorrentes, e, dessa forma, alcançar um maior poder de mercado, sem ter a necessidade de diminuir a sua margem de lucro. Ou então, este mesmo empresário pode manter os preços iguais aos dos demais concorrentes, e, com isso, aumentar arbitrariamente seus lucros, por meio da apropriação de valores que deveriam ter sido repassados ao erário.

42 GODOY, Luciano de Souza; BASSO, Juliana Penha. Sonegação e inadimplência contumaz: prejuízo à concorrência empresarial. Revista da Escola Superior da Advocacia Pública do Estado do Rio Grande do Sul, n. 2, 10 abril de 2014. Disponível em: <http://www.esapergs.org.br/ revistadigital/wp-content/uploads/2015/07/SONEGA\%C3\%87\%C3\%83O_E_INADIMPLENCIA_CONTUMAZ.pdf>. Acesso em: 6 dez. 2016. 
-. Tributação, direitos fundamentais e desenvolvimento

A inadimplência de débitos que tenham como credora a Fazenda Pública são potencialmente causadoras de danos à livre concorrência, cabendo ao Estado combater a sonegação como forma de manter o equilíbrio competitivo do mercado.

Também, a inadimplência significa menos recursos nos cofres públicos prejudicando a estrutura estatal e o atendimento às necessidades coletivas, bem como mais execuções fiscais para executar esses créditos, abarrotando o acervo do Judiciário.

\subsection{A Fazenda Pública como exequente}

Uma das questões a que se poderia atribuir à demora do curso das execuções fiscais baseia-se nas prerrogativas processuais inerentes à Fazenda Pública, aqui entendidas como necessárias e não potencial causadora da síndrome da inefetividade das execuções fiscais.

Ora, tendo em vista o grande número de execuções fiscais em trâmite, não é muito surpreendente que se diga que a Administração Pública, representada judicialmente pelas Procuradorias respectivas, atue em inúmeros processos. Ainda, soma a esse numerário todas as açôes decorrentes de descumprimento de deveres sociais prestacionais imputados ao Poder Público.

O Poder Público é responsável por significativa parcela das ações judiciais movimentadas todos os anos ${ }^{43}$. Assim, ante o montante de processos em que a Administração figura, quer como autora ou ré, faz-se necessárias as prerrogativas processuais próprias à Fazenda Pública, dentre as quais sobressaem a remessa necessária (art. 496, CPC) e a prerrogativa de prazos diferenciados, com intimação pessoal (art. 183, CPC), que tornam os processos nos quais façam parte com um procedimentos mais longos quando comparado com processo apenas entre particulares, por exemplo.

Apesar das críticas acerca da constitucionalidade das regras diferenciadas que são conferidas à Fazenda Pública no processo, para Leonardo Carneiro da Cunha, não há qualquer ofensa ao princípio da isonomia, sendo válidas em razão do interesse público. $\mathrm{O}$ autor ainda ressalta que tais prerrogativas justificam-se "pelo excessivo volume de trabalho, pelas dificuldades estruturais da Advocacia Pública e

\footnotetext{
VARGA, Caio Amuri. Desjudicialização das execuçôes fiscais tributárias como medida de auxílio ao descongestionamento do Poder Judiciário. 2015. Dissertação (Mestrado em Direito) - Universidade Presbiteriana Mackenzie, São Paulo, p. 27-28.
} 
pela burocracia inerente à sua atividade que dificulta o acesso aos fatos, elementos e dados da causa" 4 .

No que tange as execuções fiscais, as prerrogativas não justificam isoladamente a estagnação da situação da taxa de congestionamento. Entendemos que tais vantagens fazem-se necessárias considerando o volume de atribuições das Procuradorias federais, estaduais e municipais, bem como sua estrutura deficitária, e que sua eventual extinção não trariam impacto positivo quanto a eficiência das execuções fiscais devendo ser buscadas outras possibilidades que verdadeiramente favoreçam a satisfação do crédito público.

\subsection{Práticas destinadas à diminuição do acervo das execuções fiscais no âmbito do Judiciário}

A preocupação com as execuções fiscais expandiu da esfera das Procuradorias que trabalham para estabelecer metas e rotinas administrativas que tornem sua atuação mais incisiva na recuperação de seus créditos, e avança para a esfera do Poder Judiciário que vem se preocupando cada vez mais com as consequências de tantas ações executivas em trâmite, bem como alcança estudiosos do campo do Direito Tributário e até mesmo da Economia.

Nessa efervescência de pontos de vista e a evidente necessidade de se alterar os sistemas, surgem propostas para aprimorar o sistema que vigora, bem como algumas inovações.

Os Tribunais de Justiça fitos no cenário das execuções fiscais buscam medidas que visam desafogar seus acervos, como, por exemplo, o Programa Acelerar do Tribunal de Justiça de Goiás e o Projeto Execução Eficiente do Tribunal de Justiça de Minas Gerais (TJMG).

O Programa Acelerar lançado em 30 de setembro de 2013 pelo presidente do Tribunal de Justiça do Estado de Goiás (TJGO) à época, desembargador Ney Teles de Paula, a fim de reduzir pela metade os processos em tramitação. O Projeto criou coordenadorias para enfrentar o congestionamento em áreas específicas do Judiciário goiano, e entre elas a Coordenadoria de Execução Fiscal.

O Programa Acelerar - Execuções Fiscais tem como meta a propositura de mecanismos e a sistematização de procedimentos, visando uma gestão eficiente do

44 CUNHA, Leonardo José Carneiro da. A Fazenda Pública em juízo. 13. ed. Rio de Janeiro: Forense, 2016, p. 36. 
•• Tributação, direitos fundamentais e desenvolvimento

acervo das ações de execução fiscal municipal e estadual, no âmbito do Estado de Goiás, que correspondem a 29\% de todo o acervo do judiciário do Estado, para diminuir a taxa de congestionamento específica às essa classe de açôes ${ }^{45}$.

O programa almeja além da excelência na gestão de custos operacionais destes processos, alavancar o emprego de meios extrajudiciais e garantir a agilidade, a qualidade e a eficiência na tramitação dos processos executivos fiscais fortalecendo as relações e a integração entre o Tribunal, as Prefeituras goianas e o Estado. Segundo o próprio $\mathrm{TJGO}^{46}$ uma das demandas a ser enfrentada é o ajuizamento de execuções fiscais de valores ínfimos.

Da mesma forma, o Tribunal de Justiça de Minas Gerais em parceria com o Tribunal de Contas do Estado e Prefeituras mineiras criou o Projeto Execução Fiscal Eficiente, instituído pela Portaria Conjunta n. 373, de 2014, e sua missão é a redução da taxa de congestionamento dos processos relativos às ações de execução fiscal municipal e estadual de Minas Gerais, atribuindo agilidade, qualidade e eficiência na tramitação dos processos judiciais e administrativos relacionados a créditos de natureza fiscal ou administrativa, bem como a excelência na gestão de custos operacionais, e incentivar a atuação sustentável da Instituição e a integração com outros tribunais, poderes e instituições ${ }^{47}$.

As execuções fiscais de valores inferiores ao custo do processo é um dos focos abordados pelo Projeto, que propõe a busca de alternativas para extinguir processos de execução de dívida ativa em andamento nessa situação e o cancelamento administrativo daqueles débitos ínfimos ainda não ajuizados evitando a entrada de novas execuções fiscais. Outra proposta do Projeto é o incentivo ao protesto das Certidōes de Dívidas, assunto que discorreremos mais adiante.

A morosidade do Judiciário preocupa não só os representantes da estrutura do Poder em questão. Aliado ao grande número de execuções fiscais em trâmite, que nem sempre recuperam o valor da dívida também, é preocupação do Poder

TRIBUNAL DE JUSTIÇA DE GOIAS. Acelerar: execução fiscal. Disponível em: <http:// www.tjgo.jus.br/index.php/projetos-em-execucoes/programas-projetos-e-acoes/projeto-acelerar/execucao-fiscal>. Acesso em: 15 jan. 2017.

46 PAPINI, Patrícia. Acelerar: divisor de águas no Judiciário goiano. Revista TJGO. edição 18, ano 5, 2014. Disponível em: <http://docs.tjgo.jus.br/institucional/departamentos/comunicacao_social/revista_TJGO_18_w_.pdf >. Acesso em: 13 maio 2017.

47 TRIBUNAL DE JUSTIÇA DE MINAS GERAIS. Cartilha execução fiscal eficiente. Disponível em: <http://www.tjmg.jus.br/data/files/E3/A3/F4/96/18F6E4105A4805E40D4E08A8/ Cartilha_WEB.pdf $>$. Acesso em: 21 dez. 2016. 
As execuções fiscais e o protesto como alternativa na recuperação dos créditos públicos

Público, das Procuradorias, de estudiosos e doutrinadores do ramo tributarista. Dessa forma, propõe alternativas para recuperação do crédito público.

\section{VIAS ALTERNATIVAS À EXECUÇÃO FISCAL}

Constada a ineficiência da cobrança dos créditos públicos pelo procedimento da Lei de Execuções Fiscais, outros caminhos para efetivar o modelo atual e até mesmo reformá-lo.

São proposições para viabilizar uma eficiente recuperação do crédito fiscal a transação tributária, a arbitragem e a execução fiscal administrativa.

\subsection{Da transação tributária}

Uma das alternativas na recuperação dos créditos públicos, inclusive tributários, é a transação tributária, prevista expressamente no Código Tributário Nacional, em seu artigo 171, de modo que nas condições que estabeleça, a lei pode facultar aos sujeitos ativo e passivo da obrigação tributária celebrem transação que, mediante concessões mútuas, importe em terminação de litígio e consequente extinção do crédito tributário, indicando ainda a autoridade competente.

Acerca do instituto, Hugo de Brito Machado leciona que:

Tanto como no Direito privado a transação é um acordo, que se caracteriza pela ocorrência de concessōes mútuas. Mas no Direito Tributário a transação (a) depende sempre de previsão legal; e (b) não pode ter o objetivo de evitar litígio, só sendo possível depois da instauração deste ${ }^{48}$.

Entretanto, a transação tributária ainda não foi implementada definitivamente pela ausência de uma adequada regulamentação legislativa e é cercada por questionamentos quanto ao seu cabimento à luz da ordem constitucional vigente e a indisponibilidade do crédito público.

A esse respeito Priscila Faricelli de Mendonça ${ }^{49}$ ao trabalhar a transação tributária em sua dissertação de mestrado, afirma que texto da CF não apresenta dispositivo que constitua óbice à transação tributária, e que o art. $3^{\circ}$ do CTN, refere-se à

48 MACHADO, Hugo de Brito. Curso de direito tributário. 31. ed. São Paulo: Malheiros, 2010, p. 227.

49 MENDONÇA, Priscila Faricelli de. Transação e arbitragem nas controvérsias tributárias. 2013. Dissertação (Mestrado em Direito) - Universidade de São Paulo, São Paulo, p. 140. Disponível em: <www.teses.usp.br/.../dissertacao_mestrado_final_Priscila_Faricelli_de_Mendonca. pdf>. Acesso em: 20 maio 2017. 
•• Tributação, direitos fundamentais e desenvolvimento

indisponibilidade das atividades de constituição, cobrança, e arrecadação do tributo, não trazendo qualquer menção à indisponibilidade do crédito tributário isoladamente. Acrescenta ainda que o acordo entre fisco e contribuinte, tecnicamente, não acarreta disposição ou renúncia ao crédito tributário, significando solução mais adequada ao conflito e, consequentemente, mais benéfica também ao erário.

A transação no âmbito tributário já foi objeto de apreciação do Supremo Tribunal Federal ${ }^{50}$, e é aceita pela Corte como modalidade extintiva do crédito tributário e não consiste em favores fiscais, portanto, não ofenderia os artigos $150, \$ 6^{\circ}$ e $155, \$ 2^{\circ}$, XII, g, da CF.

Em que pese as divergências entre os doutrinadores sobre a possibilidade ou não da utilização da transação no âmbito tributário, fato é que o insucesso do modelo vigente requer aprimoramentos e quem sabe, a adoção novas modalidades de cobrança das dívidas públicas, como a transação, torne-se aliadas ampliando as hipóteses do contribuinte ou responsável tributário em resolver o litígio para com o Estado e contribuindo, ainda, para o desafogamento do Poder Judiciário no tocante aos processos de execuções fiscais.

\subsection{Da arbitragem tributária}

Fredie Didier Jr define a arbitragem como "técnica de solução de conflitos mediante a qual os conflitantes buscam em uma terceira pessoa, de sua confiança, a solução amigável e 'imparcial' do litígio", ou seja, trata-se de heterocomposição conferida, opcionalmente, à pessoas capazes para solução de litígios que envolvam acerca de direitos disponíveis ${ }^{51}$.

A impossibilidade de a Justiça oferecer uma resposta em tempo adequado para as demandas, dentre outros fatores, acabam por transformar a solução judicial de conflitos em algo antieconômico. Assim, a arbitragem vem ganhando cada vez mais força, deixando de ser um instituto puramente jurídico para servir de um instrumento de economia ${ }^{52}$, sendo utilizada até mesmo nos contratos administrativos.

50 STF. ADI 2.405 MC/RS, Relator Ministro Carlos Brito, Data do julgamento 06.11.2002, Tribunal Pleno, data de publicação DJ 17.02.2006.

51 DIDIER JR., Fredie. Curso de direito processual civil: introdução ao direito processual civil, parte geral e processo de conhecimento. 17. ed. Salvador: JusPodivm, 2015.

52 COELHO, Bernardo Bichara Faria. Breves considerações acerca da arbitragem e os princípios da Administração Pública. Revista de Direito da Procuradoria Geral, Procuradoria Geral do Estado do Rio de Janeiro. Junho 2014, p. 55. 
As execuções fiscais e o protesto como alternativa na recuperação dos créditos públicos

A arbitragem no âmbito Tributário é fruto de construção doutrinária ${ }^{53}$, diferentemente da transação tributária que é prevista no Código Tributário Nacional.

Entretanto, na Câmara dos Deputados tramita o PL 5082/200954, que dispóe acerca da arbitragem tributária, de iniciativa do Poder Executivo com intuito de construir nova relação entre a administração tributária e os contribuintes, possibilitando que, mediante entendimento direto, ambas as partes alcancem uma aplicação mais homogênea da legislação tributária, através da arbitragem.

A apresentação do projeto compõe um conjunto de medidas destinadas a tornar a sua atuação da modernização da Administração Fiscal mais transparente, célere, desburocratizada e eficiente.

O Ministério da Fazenda, pela Advocacia-Geral da União, justificou a propositura do PL 5082/2009, da seguinte forma:

Assim sendo, a transação traduzir-se-á em uma maior participação do contribuinte na administração tributária, o que implica uma significativa mudança de paradigmas na relação Estado/contribuinte. Para a Fazenda Nacional, a vantagem será a realização imediata de créditos tributários, sem os altos custos do processo judicial, o que, sem dúvida, vem ao encontro do interesse público. Ademais, a adoção desses meios alternativos, a médio prazo, desafogará as instâncias administrativas de julgamento e o Poder Judiciário. Também é certo que a transação tributária importará em maior segurança jurídica para o contribuinte, bem como no aperfeiçoamento e uniformização da interpretação das normas tributárias no âmbito da Administração Fiscal. De fato, o Anteprojeto prevê o julgamento por um órgão técnico especializado, único apto a lidar com a grande complexidade da legislação tributária pátria, garantindo, assim, a resolução eficiente, segura e justa dos litígios tributários. Além disso, terá efeitos significativos para aliviar o Poder Judiciário e as instâncias administrativas de julgamento, diminuir a litigiosidade na aplicação da legislação tributária, permitir a maior eficiência na arrecadação dos tributos e o aumento do cumprimento voluntário das obrigaçôes tributárias, com a eliminação dos desperdícios públicos decorrentes da sistemática em vigor. ${ }^{55}$ (grifo nosso)

53 RAKAUSKAS, Sérgio Ricardo Caires. Desjudicialização da execução fiscal e eficiência na gestão econômico-tributária: novos paradigmas para o Poder Judiciário. 2015. Dissertação (Mestrado em Direito) - Universidade Nove de Julho - Uninove, São Paulo, p. 69.

54 CÂMARA DOS DEPUTADOS. Ficha de tramitação PL 5082/2009. Disponível em: <http:// www.camara.gov.br/proposicoesWeb/fichadetramitacao?idProposicao=431269>. Acesso em: 5 abr. 2017.

55 CÂMARA DOS DEPUTADOS. Inteiro teor PL 5.082/2009. Disponível em: <http://www. camara.gov.br/proposicoesWeb/prop_mostrarintegra? codteor $=648733 \&$ filename $=$ PL+5082/2009>. Acesso em: 5 abr. 2017. 
-. Tributação, direitos fundamentais e desenvolvimento

Devemos aguardar que o Legislativo promova a entrada de tal alternativa ao ordenamento jurídico pátrio, e de que forma se dará considerando que o projeto original já sofreu emendas.

\subsection{Execução administrativa da dívida ativa dos entes federados (PL 5.080/2009)}

São atividades do Fisco a constituição, cobrança, e arrecadação do tributo, entretanto, quando necessária recuperação forçada do crédito público, o modelo jurídico adotado no ordenamento brasileiro, estabelece o uso da via judicial.

Ante ao insucesso das execuções fiscais judiciais, propõe que se atribua poderes ao Fisco para promover a execução fiscal pela via administrativa, sistemática já utilizada em países como Portugal, Espanha, Estados Unidos, França e Argentina. Na Alemanha, a mesma autoridade encarregada de lançar tributos pode, diante do perigo de inadimplência, decretar arresto de bens. Nos Estados Unidos, administrativamente pode se penhorar inclusive os salários do contribuinte inadimplente. ${ }^{56}$

No Brasil, o assunto foi tratado no Projeto de Lei n. 5080/2009, conhecido como Nova Lei de Execução Fiscal57, atualmente em trâmite na Câmara dos De$\operatorname{putados}^{58}$, que modernizaria a cobrança da dívida ativa da União, dos Estados, do Distrito Federal, bem como de suas autarquias e fundações de direito público, sendo o regime facultado aos Municípios, às suas autarquias e fundações de direito público.

56 GOMES, Marcus Lívio. Perspectivas para a execução fiscal no Brasil: execução fiscal judicial x execução fiscal administrativa - qual o melhor caminho? Revista CEJ, Rio de Janeiro: América do Norte, v. 13, n. 45, p. 86-101, abr./jul. 2009. Disponível em: <http:// www.cjf.jus.br/ojs2/index.php/revcej/article/view/1168/1263>. Acesso em: 6 jun. 2017, p. 89-91.

57 VIRGÍliO, Renata Espíndola. Possibilidade de protesto da Certidão de Dívida Ativa (CDA) pela Fazenda Pública, por falta de pagamento do crédito exequendo. Jus Navgandi, Teresina, ano 15, n. 2.525, 31 de maio de 2010. Disponível em: <https://jus.com.br/artigos/14946/possibilidade-de-protesto-da-certidao-de-divida-ativa-cda-pela-fazenda-publica-por-falta-de-pagamento-do-credito-exequendo>. Acesso em: 25 jun. 2017.

58 CÂMARA DOS DEPUTADOS. Ficha de tramitação PL 5080/2009. Disponível em: <http:// www.camara.gov.br/proposicoesWeb/fichadetramitacao?idProposicao=43>. Acesso em: 5 abr. 2017. 
O projeto de lei parte da premissa de que a origem do problema é o início da ação executiva fiscal independente da análise da viabilidade da cobrança e sem a indicação de qualquer bem passível de penhora ${ }^{59}$.

O projeto de lei possibilita a Administração, após 60 dias da inscrição da dívida ao devedor, realizar atos de constrição patrimonial e avaliação de bens (art. 9o) que deverão ser confirmados pela autoridade judiciária, convolando em penhora ou arresto, e o ajuizamento da execução fiscal por parte da Fazenda Pública deverá ocorrer, no prazo de trinta dias, contados da efetivação da primeira constrição (art. 13). Tal constrição é preparatória ao ajuizamento da execução fiscal, portanto, trata-se de limitar a distribuição apenas daquelas demandas em que haja bens do devedor para serem executados.

Do ponto de vista constitucional, Carlos Francisco Lopes Melo ${ }^{60}$ defende que a execução administrativa é viável em combate a falência da sistemática atual, constituindo mudança significativa no modelo executório vigente.

Ao analisar questões relacionadas à conveniência político - institucional das proposições apresentadas a fim de transferir atos da execução fiscal para a esfera administrativa, Marcus Lívio Gomes, argumenta pela inconveniência, elencando motivos dos quais colacionamos os seguintes:

Primeiro, em virtude da perda de poderes em benefício do Poder Executivo, que passaria a exercer atribuições historicamente jurisdicionais, em especial a constrição dos bens do devedor (penhora). Segundo, porque este anteprojeto de execução fiscal administrativa foi alardeado como a redenção da cobrança fiscal. Ou seja, já que o Judiciário é ineficiente para a cobrança executiva, passa-se ao próprio credor, o que inverte a ordem natural da cobrança sem motivos sólidos. Todavia, não se comenta acerca da notória lentidão dos órgãos do contencioso administrativo (Delegacias de Julgamento, Conselhos de Contribuintes etc.), que levam anos a fio para julgar em definitivo o lançamento tributário, atrapalhando, com isso, qualquer resquício de sucesso na posterior cobrança executiva do débito fiscal. (...) Quarto, porque a PGFN, assim como os demais credores públicos, não tem estrutura nem para movimentar os feitos executivos fiscais como parte, quanto mais para agir concomitantemente como parte

59 GONÇALVES, Marcelo Barbi. Execução fiscal: um retrato da inoperância, o (bom) exemplo português e as alternativas viáveis. Revista de Direito da Procuradoria Geral, Procuradoria Geral do Estado do Rio de Janeiro. Junho 2015, p. 211.

60 MELO, Carlos Francisco Lopes. Execução fiscal administrativa à luz da Constituição Federal. Disponível em: <http:/www.agu.gov.br/page/download/index/id/8356880>. Acesso em: 20 maio 2017. 
-. Tributação, direitos fundamentais e desenvolvimento

e presidente da cobrança executiva fiscal. Em outras palavras, o anteprojeto do Poder Executivo, para ser implementado a contento, careceria de um expressivo - e, pois, inalcançável a curto e médio prazo - volume de recursos, recursos esses que poderiam, de forma ordenada e criteriosa, ser destinados à melhoria de toda a estrutura que o Poder Judiciário já tem montada. (...) Sexto, já que o fisco quer tomar para si a responsabilidade dos atos administrativos da execução fiscal, por que ele não se responsabiliza pela alienação antecipada prevista no Código? Ou seja, uma vez penhorado o bem, a própria Fazenda Pública faz a remoção e vende-o como quiser, na hora que quiser, pelo preço de avaliação judicial não impugnada. Sétimo, a Fazenda Nacional poderia apresentar os bens do executado passíveis de penhora já na inicial, o que tornaria desnecessária a alteração legislativa proposta. Oitavo, a Fazenda Nacional poderia deixar de recorrer das matérias já pacificadas pelos tribunais superiores, o que acarretaria uma maior celeridade processual aos feitos de grandes e médios devedores cuja possibilidade de satisfação do crédito é maior. ${ }^{61}$

$\mathrm{O}$ autor ainda comenta que a desjudicialização poderia ser prejudicial ao Poder Judiciário, que teria suas verbas reduzidas e que a medida poderia surtir efeito contrário se considerados os possíveis mandados de segurança e demais processos iniciados pelas alegações dos contribuintes, da ocorrência de atos abusivos e irregulares no curso da cobrança executiva em sede administrativa.

A Comissão Especial de Assuntos Tributários da Ordem dos advogados do Brasil, Seção de São Paulo, no ano seguinte à apresentação dos projetos de lei que instituiriam mecanismos de desjudicialização da cobrança executiva fiscal, divulgou parecer que considera tais medidas como "ofensivas ao que, historicamente, se conhece como Estado Democrático de Direito"62.

A execução fiscal administrativa, no Brasil, é rodeada de uma série de questionamentos observados a estrutura das Procuradorias e a inexperiência nessa modalidade executiva fiscal.

\subsection{Outras vias já adotadas}

Um caminho à satisfação do crédito que vem sendo adotado pelas Procuradorias é a atualização do cadastro dos contribuintes de forma periódica, o que facili-

${ }^{61}$ GOMES, Marcus Lívio. Perspectivas para a execução fiscal no Brasil: execução fiscal judicial x execução fiscal administrativa - qual o melhor caminho? Revista CEJ, Rio de Janeiro: América do Norte, v. 13, n. 45, p. 86-101, abr./jul. 2009 Disponível em: <http:/www.cjf.jus.br/ ojs2/index.php/revcej/article/view/1168/1263>. Acesso em: 6 jun. 2017, p. 89-91.

62 ORDEM DOS ADVOGADOS DO BRASIL. Seção de São Paulo. São Paulo, 2010. Disponível em: <http://s.conjur.com.br/dl/parecer-oab-execucao-fiscal-admi.pdf>. Acesso em: 16 jun. 2017. 
As execuções fiscais e o protesto como alternativa na recuperação dos créditos públicos

taria a localização do mesmo em caso de inadimplência e o convênio das Procuradorias com cartórios de registros de imóveis e registro de pessoas naturais e de pessoas jurídicas e o protesto extrajudicial das certidôes de dívida ativa. Essa última alternativa será discutida em capítulo próprio.

De mesmo modo, visando otimizar a atuação das Procuradorias, as Fazendas Públicas estaduais e municipais de todo Brasil deveriam ser legalmente desobrigadas à cobrança executiva de créditos ínfimos, priorizando os grandes devedores ${ }^{63} \mathrm{e}$ os devedores contumazes, prática que já ocorre na União autorizada pela Portaria do Ministério da Fazenda n. 75 de 22 de março de $2012^{64}$. A União está autorizada a ajuizar execuções fiscais cujo montante seja superior (art. 2o) a $\mathrm{R} \$ 20.000,00$ (vinte mil reais), sendo que para valores iguais ou inferiores, necessariamente, serão adotados de outros meios de cobrança mais econômicos ${ }^{65}$.

Ainda, é uma alternativa a Fazenda credora propor acordos coletivos aos devedores como o Programa Concilia Rio da Prefeitura Municipal do Rio de Janeiro, instituído pela Lei Municipal n. 5.854/2015, atualmente objeto da Lei Municipal n. 6.156/1766, que "estimula os acordos de conciliação, com a redução do montante devido a títulos de encargos moratórios, e propõe a implantação de incentivos para reduzir o elevado número de processos que congestionam o Judiciário". Segundo a Prefeitura, no ano de instituição do Concilia Rio, em apenas doze dias cerca de 30 mil pessoas foram atendidas e $\mathrm{R} \$ 1,7$ bilhão em débitos foram negociados ${ }^{67}$.

63 SILVA, Ronaldo Campos e. Mecanismos para a efetividade da execução fiscal. 2012. Trabalho monográfico, p. 21.

64 MINISTÉRIO DA FAZENDA. Portaria n. 75 de 2011. Diário Oficial da Uniāo. Disponível em: <http://www.pgfn.fazenda.gov.br/arquivos-de-noticias/portaria-mf-no-75-2012-revoga-portaria-mf-49-2004.pdf>. Acesso em: 20 jun. 2017.

65 PROCURADORIA GERAL DA FAZENDA NACIONAL. Mudanças no ajuizamento de execuçôes fiscais pela PGFN. 2012. Disponível em: <http:/www.pgfn.fazenda.gov.br/noticias/ mudancas-no-ajuizamento-de-execucoes-fiscais-pela-pgfn>. Acesso em: 20 jun. 2017.

66 ESTADO DO RIO DE JANEIRO. Lei Estadual do Estado do Rio de Janeiro n. 6.156, de 27 de abril de 2017. Dispóe sobre o retorno do Programa Concilia Rio e dá outras providências. Disponível em: <http://smaonline.rio.rj.gov.br/legis_consulta/53801Lei\%206156_2017.pdf>. Acesso em: 20 jun. 2017.

67 ROMAR, Juliana. Concilia Rio atende 30 mil pessoas e é prorrogado até dezembro. Prefeitura da Cidade do Rio de Janeiro. Disponível em: <http://transparenciacarioca.rio/web/guest/ exibeconteudo?id=5556829>. Acesso em: 15 jun. 2017. 
•• Tributação, direitos fundamentais e desenvolvimento

\section{A COBRANÇA DE CRÉDITOS PÚBLICOS POR MEIO DE PROTESTO EXTRAJUDICIAL DAS CERTIDÕES DE DÍVIDA ATIVA}

\subsection{O protesto na seara fiscal}

O protesto de títulos é um antigo instituto do Direito Cambial, com berço no século XIV. ${ }^{68}$ É uma prática muito comum no mercado, em que o credor opta por um meio mais simples, evitando a propositura de uma ação judicial, que pressupõe litígio e custas processuais ${ }^{69}$. Além de atestar a inadimplência de determinado devedor, é mecanismo de coerção, pois, após a lavratura do protesto, o devedor é inscrito nos cadastros de inadimplentes, e intimado para pagar o débito junto ao Cartório Extrajudicial respectivo.

O protesto tem início quando o credor apresenta o título ao tabelionato de protesto requerendo o protesto e informando os dados e endereço do devedor. Após exame do tabelião, inexistindo vícios formais, o mesmo intima o devedor indicado para que, no prazo de três dias, pague a dívida, acrescido de emolumentos, junto ao cartório ou providencie a sustação do protesto antes de ele ser lavrado. Caso o devedor fique inerte ou não consiga sustar o protesto e o apresentante não desista do protesto, será lavrado e registrado o protesto.

A Lei $n^{\circ} 9.492 / 97^{70}$ regula o protesto extrajudicial, e o define como ato público, formal e solene, realizado pelo tabelião, com o escopo de provar a inadimplência e o descumprimento de obrigação constante de título de crédito ou de outros documentos de dívida.

Então, podem ser objeto de protesto títulos de crédito (cheque, letra de câmbio, duplicata, nota promissória, por exemplo) e outros documentos de dívidas. Visto a possibilidade de documentos de dívida iniciou-se a discussão sobre o que essa definição abarcaria, bem como se era possível e conveniente aplica-lo às certidões de dívida ativa da Fazenda Pública.

68 LIMA, Marcelo Cordeiro de; MIRANDA, Maria Bernadete. Protesto de títulos extrajudiciais. Disponível em: <http:/www.direitobrasil.adv.br/arquivospdf/revista/revistav42/alunos/Mar20102.pdf>. Acesso em: 20 jun. 2017.

69 CIGNACHI, Gustavo Chies. O protesto da certidão de divida ativa. Disponível em: <http:// bdjur.stj.jus.br/jspui/bitstream/2011/92168/protesto_certidao_divida_cignachi.pdf>. Acesso em: 15 jun. 2017.

70 BRASIL. Lei n. 9.492, de 10 de setembro de 1997. Define competência, regulamenta os serviços concernentes ao protesto de títulos e outros documentos de dívida e dá outras providências. Disponível em: <http://www.planalto.gov.br/ccivil_03/leis/L9492.htm>. Acesso em: 10.06.2017. 
As execuções fiscais e o protesto como alternativa na recuperação dos créditos públicos

O Fisco concluiu pela possibilidade de utilização do protesto extrajudicial como técnica de cobrança do crédito tributário, e foi massacrada de críticas pela doutrina $^{71}$.

Contrariamente à possibilidade de se protestar a certidão de dívida ativa, argumentava-se que a Fazenda Pública já possuía meio próprio para a cobrança do título executivo, título esse já dotado de presunção de certeza e liquidez ${ }^{72}$. Além disso, o protesto das CDAs era tido como sanção política, repudiado pelo ordenamento jurídico brasileiro ${ }^{73}$.

$\mathrm{Na}$ mesma linha, Hugo de Brito Machado inadmitia o protesto da Certidão de Dívida Ativa vez que desnecessário para a propositura da execução fiscal, constituindo em abuso, que apenas tem o efeito de causar dano ao contribuinte, sem qualquer proveito para a Fazenda Pública $^{74}$.

Apesar das críticas ferozes contra o protesto de certidóes de dívida ativa, este vinha sendo determinado através de atos administrativos e realizado pelas procuradorias, sendo exemplos a Lei Estadual n. 5.351/2008 ${ }^{75}$ do Rio de Janeiro e a Portaria da PGFN n. 321, de 06 de abril de $2006^{76}$.

O tema era controvertido na jurisprudência. A Primeira Turma do Supremo Tribunal Federal a entendia pela "ausência de interesse em levar a protesto a Certidão da Dívida Ativa, título que já goza de presunção de certeza e liquidez e confere

71 CAVALCANTE, Colares Mantovanni. Alguns efeitos do protesto de certidão de divida ativa em relação ao crédito tributário. Instituto Brasileiro de Estudos Tributários. Disponível em: $<$ http://www.ibet.com.br/download/mantovanni\%20colares\%20cavalcante.pdf $>$. Acesso em: 15 jun. 2017.

72 GODOI, Marilei Fortuna et al. Execução fiscal aplicada. Analise pragmática do processo de execução fiscal. Salvador, 2015, p. 84.

73 FARO, Maurício Pereira; MOREIRA, Bernardo Motta. Protesto de certidão de dívida ativa: Inaplicabilidade com a cobrança de créditos por meio de execução fiscal. Revista Brasileira de Direito Tributário, n. 18, p. 50-53, jan./fev. 2010.

74 MACHADO, Hugo de Brito. Protesto de certidão de dívida ativa. Revista Dialética de Direito Tributário, n. 130, 2006, p. 34.

75 ESTADO DO RIO DE JANEIRO. Lei Estadual n. 5.351, de 15 de dezembro de 2008. Dispões sobre medidas para incremento da cobrança de créditos inscritos em Dívida Ativa do Estado do Rio de Janeiro, altera a Lei n. 1582, de 04 de Dezembro de 1989, e dá outras providências. Disponível em: <http://alerjln1.alerj.rj.gov.br/CONTLEI.NSF/e9589b9aabd9cac8032564fe0065a bb4/266c8f1785e6494b8325752400714bca?OpenDocument>. Acesso em: 21 jun. 2017.

76 BRASIL. Ministério da Fazenda Nacional. Portaria n. 321, de 6 de abril de 2006. Dispõe sobre o protesto de Certidão de Dívida Ativa da União. Disponível em: <http://www.inmetro.gov. br/legislacao/laf/pdf/LAF000217.pdf>. Acesso em: 5 jun. 2017. 
•• Tributação, direitos fundamentais e desenvolvimento

publicidade à inscrição do débito na dívida ativa" (Agravo de Instrumento $\mathrm{n}$. 936.606/ $\mathrm{PR}^{77}$, Agravo de Instrumento n. 1.316.190/ $\mathrm{PR}^{78}$ ). E pouco tempo depois, a Segunda Turma do mesmo Tribunal fixou a tese de que "No regime instituído pelo art. $1^{\circ}$ da Lei $9.492 / 1997$, o protesto, instituto bifronte que representa, de um lado, instrumento para constituir o devedor em mora e provar a inadimplência, e, de outro, modalidade alternativa para cobrança de dívida, foi ampliado, desvinculando-se dos títulos estritamente cambiariformes para abranger todos e quaisquer 'títulos ou documentos de dívida"' (Recurso Especial n. 1.126.515/PR ${ }^{79}$ ).

$\mathrm{O}$ assunto foi submetido a apreciação do Conselho Nacional de Justiça (CNJ), através do Pedido de Providências 200910000045376. O CNJ considerou legal o protesto de certidão da dívida ativa e cabendo ao devedor arcar com os custos ${ }^{80}$.

Malgrado às críticas de que ao se protestar uma CDA conferindo ampla publicidade ao inadimplemento da dívida pública configuraria constrangimento desnecessário ao devedor e de até mesmo que poderia haver protestos indevidos e condenaçôes por danos morais ${ }^{81}$, a Lei n. 12.767, de 27 de dezembro de 2012, em seu art. 25, incluiu ao art. $1^{\circ}$ da Lei n. 9.492/97, o parágrafo único que autorizava expressamente o protesto de CDAs:

Art. $1^{\circ}(\ldots)$

Parágrafo único. Incluem-se entre os títulos sujeitos a protesto as certidōes de dívida ativa da União, dos Estados, do Distrito Federal, dos Municípios e das respectivas autarquias e fundações públicas. (Incluído pela Lei n. 12.767, de 2012)

SUPREMO TRIBUNAL FEDERAL. Decisão em Agravo de Instrumento n. 936.606-PR. Disponível em: <https://ww2.stj.jus.br/processo/revista/documento/mediado/?componente=M ON\&sequencial $=3581730 \&$ num_registro $=200701874563 \&$ data $=20080222>$. Acesso em: 10 jun. 2017.

78 STF. Decisão em Agravo de Instrumento n. 1.316.190-PR (2010/0101917-5). Disponível em: $<$ https://ww2.stj.jus.br/processo/revista/documento/mediado/?componente=MON\&sequen cial $=12888287 \&$ num_registro $=201001019175 \&$ data $=20101124>$. Acesso em: 10 jun. 2017.

79 STF. Decisão em Recurso Especial n. 1.126.515-PR. Disponível em: <https://ww2.stj.jus.br/ processo $/$ revista $/$ documento $/$ mediado $/$ ?componente $=$ ATC \&sequencial $=32558990 \&$ num_re gistro $=200900420648 \&$ data $=20131216 \&$ tipo $=5 \&$ formato $=P D F>$ Acesso em: 21 jun. 2017.

80 EUZÉBIO, Gilson Luiz. Decisão do CNJ contribui para a redução do número de execuções fiscais. Conselho Nacional de Justiça. Boletim do Magistrado, 16 dez. 2013. Disponível em: http://www.cnj.jus.br/component/acymailing/archive/view/listid-4-boletim-do-magistrado/ mailid-4916-boletim-do-magistrado?Itemid=1236. Acesso em: 6 jun. 2017.

81 FARO, Maurício Pereira; MOREIRA, Bernardo Motta. Protesto de certidão de dívida ativa: inaplicabilidade com a cobrança de créditos por meio de execução fiscal. Revista Brasileira de Direito Tributário, n. 18, jan./fev. 2010, p. 50. 
Conquanto, a questão estava longe de ser pacificada. Em 07.06.2014, foi ajuizada Ação Direta de Inconstitucionalidade n. $5135^{82}$, pela Confederação Nacional das Indústrias (CNI) cujo objeto era o parágrafo supramencionado, alegado vício de inconstitucionalidade formal e material. A seguir analisaremos a ação em comento.

\subsection{A Ação Direta de Inconstitucionalidade n. 5.135}

A despeito do vício formal, a requerente argumentou que a Lei n. 12.767/2012 foi fruto da conversão de Medida Provisória (MP n. 577/2012) que tratava da extinção das concessões de serviço público de energia elétrica e a prestação temporária do serviço sobre a intervenção para adequação do serviço público de energia elétrica, sendo o art. 25 da Lei, que introduziu o parágrafo único ao artigo $1^{\circ}$ da Lei n. 9.492/97, estranho à matéria tratada e, portanto, manifestamente inconstitucional ante a inobservância do devido processo legislativo (CF, artigos 59 e 62), além de atentar contra o princípio da separação dos poderes (CF, artigo 2o) "por conta de sua explícita falta de sintonia e pertinência temática como tema da Medida Provisória - MP n. 577/2012”. O Parlamento é competente para emendar, mas deve se ater, quanto à matéria, aos limites da proposição emanada do Chefe Executivo ${ }^{83}$.

$\mathrm{O}$ vício material consistiria na ofensa aos artigos 5\%, incisos XIII e XXXV; 170, inciso III e parágrafo único; e 174, todos da CF, ainda, o princípio constitucional da proporcionalidade.

$\mathrm{Na}$ linha argumentativa, o protesto das Certidões de Dívida Ativa, forma-se por parâmetros diversos dos demais títulos executivos, isto é, decorre de obrigação compulsória prevista em lei. Dessa forma o protesto da CDA não se prestaria a traduzir meio de prova a que se destina inicialmente o protesto, bem como não se presta a interromper o prazo prescricional ou constituir o devedor em mora para fins de fluência dos juros moratórios. Então, o mecanismo seria utilizado pela Fazenda Pública com único propósito coativo de cobrança da dívida tributária, entendida como sanção política e mera forma de execução indireta, contrariando o devido processo legal, e contrariando diretamente o direito ao processo (art. 5\%, XXXV, da Constituição Federal) assegurado aos cidadãos.

82 STF. ADI 5.135 AgR, Relator(a): Min. Roberto Barroso, julgado em 12.12.2016, publicado em 10.02.2017.

83 STF. Consulta de processo eletrônico Ação Direta de Inconstitucionalidade n. 5135-DF. Disponível em: <http://redir.stf.jus.br/estfvisualizadorpub/jsp/consultarprocessoeletronico/ConsultarProcessoEletronico.jsf? seqobjetoincidente $=4588636>$. Acesso em: 5 jun. 2017. 
•• Tributação, direitos fundamentais e desenvolvimento

Advoga que pelo protesto repercutir em restrição do crédito comercial, em razão da publicidade atribuída ao inadimplemento de uma obrigação, ao protestar a CDA haveria ofensa a livre prática de atividade econômica lícita (parágrafo único do art. $170 \mathrm{da}$ CRFB) e a liberdade do exercício profissional (artigo 5º, XIII, da CRFB).

Ademais, segundo a CNI, a medida ofenderia o princípio da proporcionalidade considerando que representa desvio de finalidade, de uso de meio inadequado e desnecessário à finalidade do protesto, sendo sua utilização pelo Fisco, incontroverso abuso de direito, não coadunando com o entendimento de meio menos gravoso para a satisfação da dívida que já goza, como se apontou, de meios próprios para a sua execução, com garantias, mas sim odioso embaraço e constrangimento para o devedor.

Foi designado com relator o ministro Roberto Barroso que julgou improcedente a ação ${ }^{84}$.

Inicialmente rejeitou a alegação de vício formal. Explicou o ministro que apesar do presente caso tratar-se da chamada prática de "contrabando legislativo", já condenada pelo STF no julgamento da ADI 5127, tal decisão teve seus efeitos modulados de modo que preservou-se, até a data do julgamento, as leis oriundas de projetos de conversão de medidas provisórias, em obediência ao princípio da segurança jurídica.

Acerca das alegações de vícios materiais, afirmou que o protesto das certidões de dívida ativa é um mecanismo constitucional legítimo de cobrança do crédito tributário, não representando uma forma de sanção política, já que não restringe de forma desproporcional os direitos fundamentais assegurados aos contribuintes. Além de que o protesto de CDA não interfere no funcionamento legítimo da empresa de forma a coagi-la a pagar impostos, sendo constitucional a criação de forma de cobrança extrajudicial para ser utilizada em vez da execução fiscal.

O ministro Barroso, enfatizou que a cobrança extrajudicial, através de protesto, é uma modalidade menos invasiva aos direitos do devedor que uma execução fiscal, que permite a penhora dos bens do devedor até o limite da dívida desde a propositura da ação judicial e também não viola o devido processo legal, como

84 STF. Notícias: STF inicia julgamento de ADI que questiona protesto de certidão de dívida ativa, 2016. Disponível em: <http://www.stf.jus.br/portal/cms/verNoticiaDetalhe.asp?idConteudo=328657>. Acesso em: 5 jun. 2017. 
alegou a CNI, ao passo que a existência de uma via de cobrança judicial da dívida com a Fazenda Pública não significa que seja a única via admitida para a recuperação de créditos tributários ou que deva ser exclusiva e não impede o contribuinte de questionar judicialmente a dívida ou a legitimidade do próprio protesto.

Os ministros Edson Fachin, Marco Aurélio e Ricardo Lewandowski, divergiram do entendimento adotado pelo relator Ministro Roberto Barroso.

Para o primeiro, incluir as CDAs no rol dos títulos sujeitos a protesto é uma sanção política que viola a atividade econômica lícita e o protesto das mesmas não coaduna com a Constituição Federal, pois há outros meios adequados e menos gravosos para efetuar a cobrança de tributos.

$\mathrm{O}$ ministro Fachin entende que o empresário com título protestado passa a ter restrições no mercado, como a dificuldade para obtenção de crédito, que podem afetar sua atividade, produzindo efeitos que vão além da execução fiscal e ofendendo o princípio da proporcionalidade.

Para o ministro Marco Aurélio, o ato normativo é eivado de inconstitucionalidade material e formal. Entende tratar-se de forma de coerção política para que o devedor quite seus débitos com a fazenda pública, bem como é norma era matéria estranha ao escopo da Medida Provisória 577, que versava sobre extinção das concessões de serviço público de energia elétrica e a prestação temporária do serviço.

Todavia, o Pleno, por maioria, julgou improcedente o pedido formulado pelo requerente, nos termos do voto do Relator, fixada tese nos seguintes termos: "O protesto das Certidóes de Dívida Ativa constitui mecanismo constitucional e legítimo, por não restringir de forma desproporcional quaisquer direitos fundamentais garantidos aos contribuintes e, assim, não constituir sanção política”.

O Supremo Tribunal Federal, ao julgar a ADI 5135/14, pacificou a discussão acerca da aplicação do protesto extrajudicial às Certidões de Dívida Ativa, decidindo pela sua constitucionalidade, afastando de uma vez por todas a ideia de sanção política que era atribuída a prática.

\subsection{Considerações acerca do instituto do protesto}

Ultrapassado os aspectos constitucionais e legais que permitem o uso do protesto extrajudicial na recuperação dos créditos públicos, convém que sejam feitas breves considerações acerca da conveniência do protesto das CDAs. 
•• Tributação, direitos fundamentais e desenvolvimento

Considerando a importância dos créditos público, necessário que para a recuperação de tais créditos, caso o particular não honre voluntariamente sua obrigação, que as Fazendas Públicas disponibilizem de mecanismo que propiciem um uso racional de seus recursos e eficiência na cobrança.

O procedimento especial para a cobrança de dos créditos fiscais através de execuções fiscais não obsta a utilização de outro meio, inclusive extrajudicial. $\mathrm{O}$ modelo das execuções fiscais esculpido na Lei n. 6830/80, apesar dos avanços como a possiblidade de bloqueio eletrônico das contas dos executados, tem-se demonstrado insuficiente e o protesto extrajudicial figura como aliado das Fazendas Públicas tornando a cobrança mais eficaz pela utilização de meio legal e reconhecido pelo Direito ${ }^{85}$.

Nos três últimos meses de 2010, no âmbito federal, 25\% dos valores protestados foram recuperados. No ano seguinte, a Procuradoria Federal encaminhou 3.616 certidôes de dívida ativa para protesto, que totalizavam aproximadamente $\mathrm{R} \$ 9,5 \mathrm{mi}$ lhôes, havendo quitação de R \$ 3,1 milhões das dívida. Já em 2012, a recuperação de recursos por meio do protesto alcançou o patamar de $\mathrm{R} \$ 9.485 .714,92$, que significou mais de $52 \%$ do valor total enviado para protesto.

Em defesa do protesto, Renata Espíndola Virgílio ${ }^{86}$ aponta:

Assim, a medida serve como mais uma atuação sobre a pessoa do devedor, na tentativa de se chegar a um consenso com este, em especial nos casos de dívidas não muito altas, que ensejariam execuções fiscais antieconômicas, prestigiando o princípio da economia processual, pois a propositura de demandas judiciais desse tipo muitas vezes tem um custo maior que o próprio débito original e, em vista do devido processo legal, devem ser processadas pelo Judiciário, o que contribui, ainda mais, para o inchaço de sua estrutura.

(...) pela alta dose de formalidade de que se reveste o atual processo judicial de execução, este se apresenta como um sistema altamente moroso, caro e de baixa eficiência, uma vez que para cada $\mathrm{R} \$ 1.000,00$ (um mil reais) cobrados por essa sistemática, apenas $\mathrm{R} \$$ 10,00 (dez reais) são efetivamente arrecadados, segundo levantamento feito no âmbito das autarquias e fundações públicas, demonstrando-se, assim, que esse modelo executivo tradicional é avesso aos princípios da eficiência e da economia processual.

85 GODOI, Marilei Fortuna et al. Execução fiscal aplicada. Analise pragmática do processo de execução fiscal. Salvador, 2015, p. 86.

86 VIRGÍlLIO, Renata Espíndola. Possibilidade de protesto da Certidão de Dívida Ativa (CDA) pela Fazenda Pública, por falta de pagamento do crédito exequendo. Jus Navgandi, Teresina, ano 15, n. 2.525, 31 de maio de 2010. Disponível em: <https://jus.com.br/artigos/14946/ possibilidade-de-protesto-da-certidao-de-divida-ativa-cda-pela-fazenda-publica-por-falta-de-pagamento-do-credito-exequendo>. Acesso em: 20 jun. 2017. 
O protesto não impede o ajuizamento das execuções fiscais, nem mesmo obsta a utilização pelo devedor da via judiciária, caso entenda indevido o protesto ou a dívida. Conquanto, a adoção do protesto desestimula a judicialização, especialmente de valores baixos, concomitantemente promove a devida e abrangente publicidade da dívida com o ente público, repercutindo em uma cobrança mais ágil e econômica para exequente e executado, afastando o pagamento de custas judiciais e encargos sucumbenciais, sendo devidos, apenas, emolumentos cartorários ${ }^{87}$, além de proporcionar uma recuperação eficiente do crédito fiscal.

\section{CONCLUSÃO}

A estagnação do processo executivo fiscal resulta em uma menor arrecadação dos recursos públicos, sendo a atual situação das execuções fiscais insustentável convergindo com o ideal de gestão eficiente do erário.

Investir na melhor recuperação dos créditos públicos significa investir no fortalecimento do Estado e de sua estrutura, bem como possibilita o atendimento as necessidades da população e a garantia dos direitos fundamentais dos administrados, mormente os de segunda geração que requerem uma prestação estatal.

A execução deve ser útil ao credor não podendo apenas servir para prejudicar o devedor e menos ainda ser prejudicial ao titular do crédito. Assim, a execução fiscal requer utilização racional dos meios executivos judiciais que pressupõe que se estabeleçam limites de valores de ajuizamento tendo em vista o proveito econômico a ser obtido, priorizando a execução judicial dos débitos de maior monta que na prática são devedores contumazes.

Admitir que qualquer valor possa ser ajuizado banaliza o processo executivo, servindo para aumentar o acervo do judiciário e o volume de trabalho das Procuradorias, resultando em uma atividade executiva ineficiente que favorece os grandes devedores e prejudica a arrecadação.

Além disso, é necessário aparelhar as Procuradorias e disponibilizar meios mais eficientes para cobrança dos créditos fiscais que o modelo da Lei n. 6830/80. Para tal, advogamos pelo protesto extrajudicial das dívidas inscritas em dívida ativa, que vem se mostrando eficiente à recuperação dos créditos públicos, sem a necessidade de dispêndio desnecessário de dinheiro público e entraves burocráticos.

87 GODOI, Marilei Fortuna et al. Execução fiscal aplicada. Analise pragmática do processo de execução fiscal. Salvador, 2015, p. 90-93. 
-. Tributação, direitos fundamentais e desenvolvimento

A transação tributária, a arbitragem tributária e a execução fiscal administrativa carecem hoje de respaldo legislativo, o que inviabiliza sua análise do plano fático e não podem ser, portanto, alternativa a curto e médio prazo à inábil cobrança dos créditos fazendários.

O protesto da Certidão de Dívida Ativa (CDA) pela Fazenda Pública, por falta de pagamento do crédito exequendo, é medida benéfica para a Administração Pública como um todo e que não viola os direitos do administrado.

A medida ainda coaduna com princípios da legalidade, da publicidade, da economia processual, da eficiência, da menor onerosidade ao devedor e da utilidade do processo de execução.

Entretanto, não deve ser interpretado como única solução. Ao contrário, compõe o caminho para o aprimoramento do sistema de cobrança do Poder Público, merecendo análise de seus efeitos a médio e longo prazo, desenvolvendo o instituto de acordo com as necessidades que venham surgir no plano fático.

\section{REFERÊNCIAS}

AMARO, Luciano. Direito tributário brasileiro. 21. ed. São Paulo: Saraiva, 2016.

BANDEIRA DE MELLO, Celso Antonio. Curso de direito administrativo. 26a . ed. São Paulo: Malheiros, 2008.

BRASIL. Constituição da República Federativa do Brasil: Texto constitucional promulgado em 5 de outubro de 1988, com as alterações adotadas pelas Emendas Constitucionais de 1 a 95 .

BRASIL. Lei n. 4320, de 17 de Março de 1964. Estatui Normas Gerais de Direito Financeiro para elaboração e controle dos orçamentos e balanços da União, dos Estados, dos Municípios e do Distrito Federal.

BRASIL. Lei n. 6830, de 22 de setembro de 1980. Dispõe sobre a cobrança judicial da Dívida Ativa da Fazenda Pública, e dá outras providências.

BRASIL. Lei $n$. 9492, de 10 de setembro de 1997. Define competência, regulamenta os serviços concernentes ao protesto de títulos e outros documentos de dívida e dá outras providências. Disponível em: <http://www.planalto.gov.br/ccivil_03/leis/L9492.htm>. Acesso em: 10 jun. 2017.

BRASIL. Ministério da Fazenda Nacional. Portaria n. 321, de 6 de abril de 2006. Dispóe sobre o protesto de Certidão de Dívida Ativa da União. Disponível em: <http://www. inmetro.gov.br/legislacao/laf/pdf/LAF000217.pdf>. Acesso em: 5 jun. 2017.

BRASIL. Ministério da Fazenda Nacional. Portaria n. 75, de 22 de março de 2012. Dispõe sobre a inscrição de débitos na Dívida Ativa da União e o ajuizamento de execuções 
As execuções fiscais e o protesto como alternativa na recuperação dos créditos públicos

fiscais pela Procuradoria-Geral da Fazenda Nacional. Diário Oficial da União, Brasília: 29 de março de 2012. Disponível em: <http://fazenda.gov.br/acesso-a-informacao/ institucional/legislacao/portarias-ministerial/2012/arquivos/portaria75.pdf> Acesso em: 20 dez. 2016.

CÂMARA DOS DEPUTADOS. Divida ativa supera arrecadação; propostas para agilizar cobrança não andam. Disponível em: <http://www2.camara.leg.br/camaranoticias/ noticias/ECONOMIA/480908-DIVIDA-ATIVASUPERA-ARRECADACAO;PROPOSTAS-PARA-AGILIZAR-COBRANCA-NAO-ANDAM.html>. Acesso em: 15 fev. 2017.

CÂMARA DOS DEPUTADOS. Projeto de Lei da Câmara dos Deputados n. 5080/2009. 2009. Disponível em: <http://www.camara.gov.br/proposicoesWeb/fichadetramitacao?i dProposicao=43>. Acesso em: 5 abr. 2017.

CÂMARA DOS DEPUTADOS. Projeto de Lei da Câmara dos Deputados n. 5082/2009. 2009. Disponível em: <http://www.camara.gov.br/proposicoesWeb/fichadetramitacao?i dProposicao $=431269>$. Acesso em: 5 abr. 2017.

CARRAZZA, Roque António. Curso de direito constitucional tributário. 27. ed. São Paulo: Saraiva, 2011.

CARVALHO FILHO, José dos Santos. Manual de direito administrativo. 27. ed. rev., ampl. e atual. até 31-12-2013. São Paulo: Atlas, 2014.

CARVALHO, Paulo de Barros. Curso de direito tributário. 23. ed. São Paulo: Saraiva, 2010.

CAVALCANTE, Colares Mantovanni. Alguns efeitos do protesto de certidão de dívida ativa em relação ao crédito tributário. Instituto Brasileiro de Estudos Tributários. Disponível em: <http://www.ibet.com.br/download/mantovanni\%20colares\%20cavalcante.pdf>. Acesso em: 15 jun. 2017.

CIGNACHI, Gustavo Chies. O protesto da certidão de divida ativa. Disponível em: <http://bdjur.stj.jus.br/jspui/bitstream/2011/92168/protesto_certidao_divida_cignachi. pdf>. Acesso em: 15 jun. 2017.

COELHO, Bernardo Bichara Faria. Breves considerações acerca da arbitragem e os princípios da Administração Pública. Revista de Direito da Procuradoria Geral, Procuradoria Geral do Estado do Rio de Janeiro. Junho 2014.

CONSELHO NACIONAL DE JUSTIÇA - CNJ. Justiça em números 2016: ano-base 2015. Brasília: CNJ, 2016. Disponível em: <http://www.cnj.jus.br/programas-e-acoes/ pj-justica-em-numeros/relatorios>. Acesso em: 2 jan. 2017.

CUNHA, Leonardo Carneiro da. A fazenda pública em juizo. 13. ed. Rio de Janeiro: Forense, 2016.

DI PIETRO, Maria Sylvia Zanella. Direito administrativo. 27. ed. São Paulo: Atlas, 2014.

DIDIER JR, Fredie. Curso de direito processual civil: introdução ao direito processual civil, parte geral e processo de conhecimento. 17. ed. Salvador: JusPodivm, 2015. 
•• Tributação, direitos fundamentais e desenvolvimento

EUZÉBIO, Gilson Luiz. Decisão do CNJ contribui para a redução do número de execuções fiscais. Conselho Nacional de Justiça. Boletim do Magistrado, 16 dez. 2013. Disponível em: <http://www.cnj.jus.br/component/acymailing/archive/view/listid-4boletim-do-magistrado/mailid-4916-boletim-do-magistrado? Itemid=1236>. Acesso em: 6 jun. 2017.

FARO, Maurício Pereira; MOREIRA, Bernardo Motta. Protesto de certidão de dívida ativa: inaplicabilidade com a cobrança de créditos por meio de execução fiscal. Revista Brasileira de Direito Tributário, n. 18, jan./fev. 2010.

GODOI, Marilei Fortuna et al. Execução fiscal aplicada. Analise pragmática do processo de execução fiscal. Salvador, 2015.

GODOY, Luciano de Souza; BASSO, Juliana Penha. Sonegação e inadimplência contumaz: prejuízo à concorrência empresarial. Revista da Escola Superior da Advocacia Pública do Estado do Rio Grande do Sul, edição n. 2, de 10 de abril de 2014. Disponível em: <http://www.esapergs.org.br/revistadigital/wp-content/uploads/2015/07/ SONEGA\%C3\%87\%C3\%83O_E_INADIMPLENCIA_CONTUMAZ.pdf>. Acesso em: 6 dez. 2016.

GOMES, Marcus Lívio. Perspectivas para a execução fiscal no Brasil: execução fiscal judicial x execução fiscal administrativa - qual o melhor caminho? Revista CEJ, Rio de Janeiro: América do Norte, v. 13, n. 45, p. 86-101, abr./jul. 2009. Disponível em: <http:// www.cjf.jus.br/ojs2/index.php/revcej/article/view/1168/1263>. Acesso em: 6 jun. 2017.

GONÇALVES, Marcelo Barbi. Execução fiscal: um retrato da inoperância, o (bom) exemplo português e as alternativas viáveis. Revista de Direito da Procuradoria Geral, Procuradoria Geral do Estado do Rio de Janeiro. Junho 2015.

GRECO, Leonardo. A reforma do processo de execução. Revista da EMERJ, v. 1, n. 1, 1998. Disponível em: <http://www.emerj.tjrj.jus.br/revistaemerj_online/edicoes/revista01/ revista01_68.pdf>. Acesso em: 19 abr. 2017.

GRECO, Leonardo. Execução civil: entraves e propostas. Revista Eletrônica de Direito Processual REDP, v. XII. Periódico da Pós-Graduação Stricto Sensu em Direito Processual da UERJ. Disponível em: <www.e-publicacoes.uerj.br/index.php/redp/article/ download/8685/6557>. Acesso em: 20 jun. 2017.

HARADA, Kiyoshi. Código Tributário Nacional: organização dos textos, índices e notas. São Paulo: Iglu, 2003.

HARADA, Kiyoshi. Direito financeiro e tributário. 25. ed. rev., atual. e ampl. São Paulo: Atlas, 2016.

IANCZKOVSKI, Elvis. O tributo e a multa: alguns pontos de convergência e divergência. Conteúdo Jurídico, Brasília-DF: 11 jun. 2012. Disponível em: <http://www.conteudojuridico. com.br/artigo,o-tributo-e-a-multa-alguns-pontos-de-convergencia-e-divergencia, 37477. html\#_edn3>. Acesso em: 20 jun. 2017. 
As execuções fiscais e o protesto como alternativa na recuperação dos créditos públicos

INSTITUTO DE PESQUISA ECONÔMICA APLICADA (Ipea). Custo unitário do processo de execução fiscal na Justiça Federal. Brasília, DF: Ipea, 2011. Disponível em: <http://repositorio.ipea.gov.br/bitstream/11058/887/1/livro_custounitario.pdf>. Acesso em: 5 mar. 2017.

INSTITUTO DE PESQUISA ECONÔMICA APLICADA (Ipea). nota técnica custo unitário do processo de execução fiscal na Justiça Federal. Brasília, DF: Ipea, 2011. Disponível em: <http:/www.ipea.gov.br/agencia/images/stories/PDFs/nota_tecnica/111230_notatecnicadiest1.pdf>. Acesso em: 5 jun. 2017.

LIMA, Marcelo Cordeiro de; MIRANDA, Maria Bernadete. Protesto de títulos extrajudiciais. Disponível em: <http:/www.direitobrasil.adv.br/arquivospdf/revista/revistav42/alunos/ Mar20102.pdf>. Acesso em: 20 jun. 2017.

MACHADO, Hugo de Brito. Curso de direito tributário. 31. ed. São Paulo: Malheiros, 2010.

MACHADO, Hugo de Brito. Protesto de certidão de dívida ativa. Revista Dialética de Direito Tributário, n. 130, 2006.

MELO, Carlos Francisco Lopes. Execução fiscal administrativa à luz da Constituição Federal. Disponível em: <http://www.agu.gov.br/page/download/index/id/8356880>. Acesso em: 2 maio 2017.

MENDONÇA, Priscila Faricelli de. Transação e arbitragem nas controvérsias tributárias. 2013. Dissertação (Mestrado em Direito) - Universidade de São Paulo, São Paulo. Disponível em: <www.teses.usp.br/.../dissertacao_mestrado_final_Priscila_Faricelli_de_Mendonca. pdf>. Acesso em: 20 maio 2017.

MINISTÉRIO DA FAZENDA. Portaria n. 75 de 2011. Diário Oficial da União. Disponível em: <http://www.pgfn.fazenda.gov.br/arquivos-de-noticias/portaria-mf-no75-2012-revoga-portaria-mf-49-2004.pdf>. Acesso em: 20 jun. 2017.

ORDEM DOS ADVOGADOS DO BRASIL. Seção de São Paulo. São Paulo, 2010. Disponível em: <http://s.conjur.com.br/dl/parecer-oab-execucao-fiscal-admi.pdf>. Acesso em: 16 jun. 2017.

PAPINI, Patrícia. Acelerar: divisor de águas no Judiciário goiano. Revista TJGO, edição 18, ano 05, 2014. Disponível em: <http://docs.tjgo.jus.br/institucional/departamentos/ comunicacao_social/revista_TJGO_18_w_.pdf>. Acesso em: 13 maio 2017.

PAULSEN, Leandro. Direito tributário: Constituição e Código Tributário Nacional à luz da doutrina e da jurisprudência. 13. ed. Porto Alegre: Livraria do Advogado; Esmafe, 2011.

PAULSEN, Leandro; AVILA, René Bergmann; SLIWIKA, Indrid Schoroder. Direito processual tributário: processo administrativo fiscal e execução fiscal à luz da doutrina e da jurisprudência. 6. ed. rev. atualizada. Porto Alegre: Livraria do Advogado, 2010.

PROCURADORIA GERAL DA FAZENDA NACIONAL. Mudanças no ajuizamento de execuçôes fiscais pela PGFN. 2012. Disponível em: <http://www.pgfn.fazenda.gov.br/noticias/ mudancas-no-ajuizamento-de-execucoes-fiscais-pela-pgfn>. Acesso em: 20 jun. 2017. 
•• Tributação, direitos fundamentais e desenvolvimento

RAKAUSKAS, Sérgio Ricardo Caires. Desjudicialização da execução fiscal e eficiência na gestão econômico-tributária: novos paradigmas para o Poder Judiciário. 2015. Dissertação (Mestrado em Direito) - Universidade Nove de Julho - Uninove, São Paulo.

RIBEIRO, C. J. de Assis. O crédito público no Brasil: teoria e prática. Cadernos de Administração Pública. Rio de Janeiro, Fundação Getúlio Vargas, 1972.

RIO DE JANEIRO. Lei Estadual do Estado do Rio de Janeiro n. 5.351, de 15 de Dezembro de 2008. Dispões sobre medidas para incremento da cobrança de créditos inscritos em Dívida Ativa do Estado do Rio de Janeiro, altera a Lei n. 1582, de 04 de Dezembro de 1989, e dá outras providências. Disponível em: <http://alerjln1.alerj.rj.gov. br/CONTLEI.NSF/e9589b9aabd9cac8032564fe0065abb4/266c8f1785e6494b8325752 400714 bca? OpenDocument>. Acesso em: 21 jun. 2017.

RIO DE JANEIRO. Lei Estadual do Estado do Rio de Janeiro n. 6.156, de 27 de abril de 2017. Dispõe sobre o retorno do Programa Concilia Rio e dá outras providências. Disponível em: <http://smaonline.rio.rj.gov.br/legis_consulta/53801Lei\%206156_2017. pdf>. Acesso em: 20 jun. 2017.

ROCHA, Dartanhan Vercingetórix de Araújo e. Análise econômica das execuções fiscais de reduzido valor e os efeitos da Lei n. 12.514/11. Revista CEJ, Brasília, ano XVI, n. 56, p. 102-110, jan./abr. 2012. Disponível em: <http://www.cjf.jus.br/ojs2/index.php/revcej/ article/view/1542/1550>. Acesso em: 3 jan. 2017.

ROMAR, Juliana. Concilia Rio atende 30 mil pessoas e é prorrogado até dezembro. PREFEITURA DA CIDADE DO RIO DE JANEIRO. Disponível em: <http:// transparenciacarioca.rio/web/guest/exibeconteudo?id=5556829>. Acesso em: 15 jun. 2017.

SABBAG, Eduardo. Manual de direito tributário. 8. ed. São Paulo: Saraiva, 2016.

SCHOUERI, Luis Eduardo. Direito Tributário. 2. ed. São Paulo: Saraiva, 2012.

SENADO FEDERAL. Glossário. Disponível em: <https://www12.senado.leg.br/ orcamento/glossario/credito-publico>. Acesso em: 23 jun. 2017.

SILVA, José Afonso da. Comentário Contextual à Constituição. 8. ed. São Paulo: Malheiros, 2010.

SILVA, Ronaldo Campos e. Mecanismos para a efetividade da execução fiscal. 2012. Trabalho monográfico - EMERJ, Rio de Janeiro. Disponível em: <http://www.emerj.tjrj. jus.br/publicacoes/concursodemonografiajuridica_premioricardolobotorres/ monografias/Ronaldo-Campos-e-Silva.pdf>. Acesso em: $21 \mathrm{dez} .2016$.

STF. Decisão n. Ação Direta de Inconstitucionalidade n. 2405 MC-RS. Disponível em: <http://redir.stf.jus.br/paginadorpub/paginador.jsp?docTP=AC\&docID =347580>. Acesso em: 10 fev. 2017.

STF. Decisão Ação Direta de Inconstitucionalidade n. 5135-DF. Disponível em: <http:// www.stf.jus.br/arquivo/informativo/documento/informativo846.htm>. Acesso em: 15 jun. 2017. 
As execuções fiscais e o protesto como alternativa na recuperação dos créditos públicos

STF. Consulta de Processo Eletrônico Ação Direta de Inconstitucionalidade n. 5135-DF. Disponível em: <http://redir.stf.jus.br/estfvisualizadorpub/jsp/consultarprocessoeletronico/ ConsultarProcessoEletronico.jsf? seqobjetoincidente=4588636>. Acesso em: 5 jun. 2017.

STF. Decisão Agravo de Instrumento n. 1.316.190-PR (2010/0101917-5). Disponível em: $<$ https://ww2.stj.jus.br/processo/revista/documento/mediado/?componente=MON\&se quencial $=12888287 \&$ num_registro $=201001019175 \&$ data $=20101124>$. Acesso em: 10 jun. 2017.

STF. Decisão em Recurso Especial n. 1.126.515-PR. Disponível em: <https://ww2.stj.jus. $\mathrm{br} / \mathrm{processo} / \mathrm{revista} / \mathrm{documento} / \mathrm{mediado} /$ ? componente $=$ ATC \&sequencial $=32558990 \&$ num_registro $=200900420648 \&$ data $=20131216 \&$ tipo $=5 \&$ formato $=P D F>$ Acesso em: 21 jun. 2017.

STF. Notícias: STF inicia julgamento de ADI que questiona protesto de certidão de dívida ativa, 2016. Disponível em: <http://www.stf.jus.br/portal/cms/verNoticiaDetalhe. asp?idConteudo=328657>. Acesso em: 5 jun. 2017.

STF. Decisão Agravo de Instrumento n. 936.606-PR. Disponível em: <https://ww2.stj.jus. $\mathrm{br} /$ processo $/$ revista $/$ documento $/$ mediado $/$ ? componente $=M O N \&$ sequencial $=3581730 \&$ num_registro $=200701874563 \&$ data $=20080222>$. Acesso em: 10 jun. 2017.

THEODORO JUNIOR, Humberto. Curso de direito processual civil. Rio de Janeiro: Forense, 2014. v. I: Teoria geral do direito processual civil e processo de conhecimento.

TORRES, Ricardo Lobo. Tratado de direito financeiro e tributário. 17. ed. Rio de Janeiro: Renovar, 2010.

TRIBUNAL DE JUSTIÇA DE GOIAS. Acelerar - Execução Fiscal. Disponível em: <http://www.tjgo.jus.br/index.php/projetos-em-execucoes/programas-projetos-e-acoes/ projeto-acelerar/execucao-fiscal>. Acesso em: 15 jan. 2017.

TRIBUNAL DE JUSTIÇA DE MINAS GERAIS - TJMG. Portaria Conjunta n. 373, de 4 de setembro de 2014. Institui, no âmbito da Justiça Comum de Primeiro Grau do Estado de Minas Gerais, o "Projeto Execução Fiscal Eficiente". Diário Oficial, Belo Horizonte: 9 set. 2014.

Tribunal de Justiça de Minas Gerais. Cartilha execução fiscal eficiente. Disponível em: <http://www.tjmg.jus.br/data/files/E3/A3/F4/96/18F6E4105A4805E40D4E08A8/ Cartilha_WEB.pdf>. Acesso em: 21 dez. 2016.

VARGA, Caio Amuri. Desjudicialização das execuçôes fiscais tributárias como medida de auxílio ao descongestionamento do Poder Judiciário. 2015. Dissertação (Mestrado em Direito) - Universidade Presbiteriana Mackenzie, São Paulo.

VIRGÍlIO, Renata Espíndola. Possibilidade de protesto da Certidão de Dívida Ativa (CDA) pela Fazenda Pública, por falta de pagamento do crédito exequendo. Jus Navgandi, Teresina, ano 15, n. 2525, 31 de maio de 2010. Disponível em: <https://jus.com.br/ artigos/14946/possibilidade-de-protesto-da-certidao-de-divida-ativa-cda-pela-fazendapublica-por-falta-de-pagamento-do-credito-exequendo>. Acesso em: 25 jun. 2017. 
